\title{
Binding of $\beta_{4} Y_{5}$ by Adenosine $A_{1}$ and $A_{2 A}$ Receptors Determined by Stable Isotope Labeling with Amino Acids in Cell Culture and Mass Spectrometry†
}

\author{
Dora Bigler Wang ${ }^{\ddagger}$, Nicholas E. Sherman ", John D. Shannonף, Susan A. Leonhardt ${ }^{\S}$, Linnia \\ H. Mayeenuddin $\ddagger$, Mark Yeager ${ }^{\S}$, and William E. Mclntire ${ }^{\ddagger}{ }^{\star}$ \\ ¥Department of Pharmacology, University of Virginia Health System, Charlottesville, Virginia \\ 22908 \\ IW.M. Keck Biomedical Mass Spectrometry Laboratory, University of Virginia Health System, \\ Charlottesville, Virginia 22908 \\ §Department of Molecular Physiology and Biological Physics, University of Virginia Health \\ System, Charlottesville, Virginia 22908
}

\begin{abstract}
Characterization of $\mathrm{G}$ protein $\beta \gamma$ dimer isoform expression in different cellular contexts has been impeded by low levels of protein expression, broad isoform heterogeneity, and antibodies of limited specificity, sensitivity or availability. As a new approach, we used quantitative mass spectrometry to characterize native $\beta \gamma$ dimers associated with adenosine $A_{1}: a_{i 1}$ and adenosine $A_{2 A}: a_{S}$ receptor fusion proteins expressed in HEK-293 cells. Cells expressing $A_{1}: a_{i 1}$ were cultured in media containing $\left[{ }^{13} \mathrm{C}_{6}\right]$ Arg and $\left[{ }^{13} \mathrm{C}_{6}\right]$ Lys, and $\beta \gamma$ labeled with heavy isotopes purified. Heavy $\beta \gamma$ was combined with either recombinant $\beta \gamma$ purified from Sf9 cells, $\beta \gamma$ purified from the $\mathrm{A}_{2 \mathrm{~A}}: \alpha_{S}$ expressed in HEK-293 cells cultured in standard media, or an enriched $\beta \gamma$ fraction from HEK-293 cells. Samples were separated by SDS-PAGE, and protein bands containing $\beta$ and $\gamma$ were excised, digested with trypsin, separated by HPLC and isotope ratios analyzed by mass spectrometry. Three $\beta$ isoforms, $\beta_{1}, \beta_{2}$ and $\beta_{4}$, and seven $\gamma$ isoforms, $\gamma_{2}, \gamma_{4}$, $\gamma_{5}, \gamma_{7}, \gamma_{10}, \gamma_{11}$ and $\gamma_{12}$ were identified in the analysis. $\beta_{1}$ and $\gamma_{5}$ were most abundant in the enriched $\beta \gamma$ fraction, and this $\beta \gamma$ profile was generally mirrored in the fusion proteins. However, both $A_{2 A}: a_{S}$ and $A_{1}: a_{i 1}$ bound more $\beta_{4}$ and $\gamma_{5}$ compared to the enriched $\beta \gamma$ fraction; also, more $\beta_{4}$ was associated with $A_{2 A}: a_{S}$ than $A_{1}: a_{i 1}$. Both fusion proteins also contained less $\gamma_{2}, \gamma_{10}$ and $\gamma_{12}$ than the enriched $\beta \gamma$ fraction. These results suggest that preferences for particular $\beta \gamma$ isoforms may be driven in part by structural motifs common to adenosine receptor family members.
\end{abstract}

\footnotetext{
$\dagger$ The work was supported by the American Heart Association National Scientist Development Grant 0535350N, a Pilot/Feasibility Award from the UVa Silvio O. Conte Digestive Disease Research Center and the National Institutes of Health Grant R01-DK-19952.

*To whom correspondence should be addressed: Department of Pharmacology, University of Virginia Health System, P.O. Box 800735, 1300 Jefferson Park Avenue, Charlottesville, Virginia 22908. Phone: 434-924-9976; Fax: 434-982-3878; wem2p@virginia.edu..
} 
The $\mathrm{G}$ protein $1 \beta \gamma$ dimer participates in the initiation of signaling cascades by coupling $\mathrm{Ga}$ subunits to $G$ protein coupled receptors (1), and once activated, $\beta \gamma$ dimers can interact with and regulate a multitude of signaling proteins (2). Function of the $\mathrm{Ga}$ isoforms has been well established with respect to specific receptor coupling and downstream signaling pathways. However, the five $\beta$ and $12 \gamma$ isoforms form a diverse constellation of $\beta \gamma$ dimers (3-5), the functional significance of which is only beginning to be appreciated. A number of powerful genetic approaches, including homologous recombination $(6 ; 7)$ and RNA interference $(8 ; 9)$ have emerged to allow deletion or attenuation of $\beta$ or $\gamma$ genes of interest. Results of these studies revealed that regulation of specific $\beta$ and $\gamma$ isoforms is tightly integrated to many elements of $\mathrm{G}$ protein coupled receptor signaling pathways. Furthermore, the advent of real time PCR has enabled the analysis of transcriptional regulation with great precision (9). In contrast, characterization of $\beta$ and $\gamma$ isoforms at the protein level has relied predominantly on antibodies; limitations in this approach, such as cross reactivity and poor sensitivity, make quantitative characterization of this family of highly related proteins fraught with difficulty.

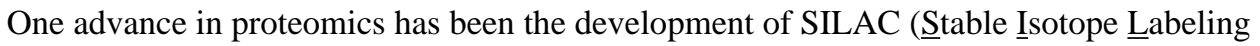
with Amino Acids in Cell Culture) for the quantitation of proteins by mass spectrometry (10). An advantage of SILAC is that protein standards can be combined with samples and treated identically during the sample preparation steps necessary for mass spectrometry, thus allowing protein quantitation with great precision. This study describes a general procedure for purifying endogenous $\beta \gamma$ dimers from cells by expressing either an epitope tagged adenosine $A_{1}$ receptor: $a_{i 1}\left(A_{1}: a_{i 1}\right)$ fusion protein or adenosine $A_{2 A}$ receptor: $a_{S}\left(A_{2 A}: a_{S}\right)$ fusion protein. After immobilization as an R:G complex on affinity beads, the receptor fusion protein can release native $\beta \gamma$ when activated with $\mathrm{AlF}^{-}$. When used in conjunction with SILAC and LC MS/MS mass spectrometry, this technique demonstrates femtomole sensitivity, the capability to identify and quantify individual $\beta$ and $\gamma$ isoforms in a mixed $\beta \gamma$ population, and the precision to discern differences in $\beta \gamma$ composition among different adenosine receptor $\mathrm{G}$ protein complexes and the overall $\beta \gamma$ profile in a cell. These attributes combine to provide a powerful approach that can be used to characterize G protein $\beta$ and $\gamma$ isoforms under a variety of experimental conditions.

\section{Materials and Methods}

\section{Construction of Recombinant Baculoviruses}

The baculovirus expressing the human $\gamma_{5}$ subunit was engineered by digestion of the pcDNA3.1+ plasmid containing $\gamma_{5}$ (Missouri S\&T cDNA Resource Center) with PmeI in order to generate a blunt end $\gamma_{5}$ insert. The baculovirus expression vector $\mathrm{pFastBac} 1^{\mathrm{TM}}$ (Invitrogen) was digested with StuI to generate linear DNA with blunt ends; the $\gamma_{5}$ insert was ligated into the vector, and cDNAs from positive clones were screened for correct orientation of insert, and verified for correct sequence. DH10bac ${ }^{\mathrm{TM}}$ cells (Invitrogen) were transformed with the $\mathrm{pFastBac1}{ }^{\mathrm{TM}}$ vector containing $\gamma_{5}$, and screening of bacmid DNA from positive clones for correct transposition was achieved by PCR. The origin of the baculoviruses encoding $6 \mathrm{HIS}^{-} \mathrm{G}_{\mathrm{i} 1} \mathrm{a}, \beta_{1}, \beta_{2}, \beta_{4}, \gamma_{2}, \gamma_{7}, \gamma_{10}, \gamma_{11}$, and $\gamma_{12}$ has been published elsewhere (11;12).

\footnotetext{
${ }^{1}$ The abbreviations used are: G protein, guanine nucleotide-binding regulatory protein; SILAC, stable isotope labeling with amino acids in cell culture; Sf9 cells, Spondoptera frugiperda cells; HEK cells, human embryonic kidney cells; DMEM, Dulbecco's Modified Eagle Medium; FBS, fetal bovine serum; DTT, dithiothreitol; CHAPS, 3-[(3-cholamidopropyl) dimethylammonio]-1propanesulfonate; EDTA, ethylenediaminetetraacetic acid; HEPES, N-(2-hydroxyethyl)piperazine- $N^{\prime}$-2-ethane-sulfonic acid; BSA, bovine serum albumin; DDM, n-dodecyl beta-D-maltoside; CHS, cholesteryl hemisuccinate; SDS, sodium dodecyl sulfate; MALDI, matrix-assisted laser desorption/ionization.
} 


\section{Expression and Purification of Recombinant $\beta y$ Dimers in Sf9 Cells}

Recombinant baculoviruses encoding the desired combination of ${ }_{6 \mathrm{HIS}}-\mathrm{G}_{\mathrm{i} 1}$ a subunit and $\beta \gamma$ dimer were used to infect Sf9 cells at an MOI of three, which were then harvested and used to purify recombinant $\beta \gamma$ dimers as described (11). This purification scheme yields a highly pure preparation of recombinant $\beta \gamma$ dimer of defined composition (Fig. 1).

\section{Design and Validation of $\beta$ and $y$ Specific PCR Primers}

PCR primers for individual $\beta$ and $\gamma$ isoforms were designed using Beacon Designer ${ }^{\mathrm{TM}}$ software and tested using end point PCR to verify a single amplicon product. Amplicons were sequenced to verify the fidelity of the primer target interaction; validated primer sets are listed in Table 1.

\section{Quantitation of mRNA by Real Time rtPCR}

Total cell RNA was extracted using the RNeasy Minikit (Qiagen); cDNAs were created with $1 \mu \mathrm{g}$ RNA using the iScript cDNA Synthesis Kit (BioRad) and quantitative real time PCR was performed using the iQ SYBER Green Supermix (BioRad) in an iCycler PCR machine (BioRad). The ribosomal protein 13A was used as an internal control reference gene. Normalization of the target gene was accomplished by using the formula $2^{(\mathrm{E} t-\mathrm{R} t)}$, where $\mathrm{E} t$ and $\mathrm{R} t$ are the threshold cycles for the experimental and reference genes, respectively (13).

\section{Construction of Plasmids}

A plasmid encoding a fusion protein of the human adenosine $A_{1}$ receptor and rat $G_{i 1} a$ was kindly provided by Dr. Graeme Milligan (University of Glasgow, Scotland, UK). Restriction enzymes BamH1 and EcoRV were used to generate an insert consisting of the $3^{\prime}$ end of the $A_{1}$ receptor and the entire $G_{i 1}$ a subunit. The same restriction enzymes were used to digest the vector pDoubleTrouble containing the adenosine $A_{1}$ receptor (14), and the fusion protein insert was ligated into the purified linearized pDoubleTrouble vector containing the HIS and FLAG epitope tags and the $5^{\prime}$ end of the $\mathrm{A}_{1}$ receptor.

Vector pcDNA3.1+ containing the gene for the human $\mathrm{G}_{\mathrm{S}}$ a short (Missouri S\&T cDNA Resource Center), was modified by PCR mutagenesis in order to facilitate the fusion of human adenosine $A_{2 A}$ receptor to $G_{S} a$. Two endogenous SmaI sites were changed in order to eliminate the restriction site: a $\mathrm{C}$ to $\mathrm{G}$ mutation in the non-coding backbone region of the plasmid DNA; the other site was internal to the $\mathrm{G}_{\mathrm{S}}$ a cDNA in which nucleotide $963(\mathrm{G})$ was mutagenized to a $(\mathrm{C})$, resulting in a silent mutation at residue R321. During the same multimutagenesis reaction (Stratagene, La Jolla, CA) a SmaI restriction site was incorporated at the $5^{\prime}$ end of the $\mathrm{G}_{\mathrm{S}}$ a cDNA. Nucleotides $1 \mathrm{~A}, 2 \mathrm{~T}, 3 \mathrm{G}$ and $6 \mathrm{C}$ of the $\mathrm{G}_{\mathrm{S}}$ a cDNA were changed to CCC and G, respectively, resulting in a SmaI site. Construction of the $A_{2 A}: G_{S}$ a fusion was completed utilizing standard PCR techniques to amplify the wild-type $\mathrm{A}_{2 \mathrm{~A}}$ gene using modified primers encoding exogenous restriction sites KpnI at the $5^{\prime}$, TTA AAC TTA AGC TTG GTA CCA TGC CCA TCA TGG GCT CCT and NcoI at the $3^{\prime}$, CCC GAG GCA GCC CAT GGA CAC TCC TGC TCC ATC CT, termini. The PCR product was digested with NcoI and filled-in using Klenow to generate a blunt end. Following subsequent digestion with KpnI, the product was subcloned by ligation into the modified pcDNA3.1+ $\mathrm{G}_{\mathrm{S}}$ a vector that had been digested with $\mathrm{KpnI}$ and SmaI. The $\mathrm{A}_{2 \mathrm{~A}^{-}} \mathrm{G}_{\mathrm{S}}$ a fusion protein construct was subcloned into the vector pDoubleTrouble by digestion of the pcDNA3.1+ vector containing $A_{2 A}: G_{S}$ a with BstEII and PmeI to produce the fusion protein insert with a blunt $3^{\prime}$ end. A pDoubleTrouble vector containing the $\mathrm{A}_{2 \mathrm{~A}}$ receptor (14) was digested with BstEII and EcoRV to produce a linearized empty vector with a blunt end at the EcoRV site; the fusion protein insert was than ligated into the vector, resulting in 
a pDoubleTrouble vector containing an $\mathrm{A}_{2 \mathrm{~A}}: \mathrm{G}_{\mathrm{S}}$ a fusion protein with a HIS/FLAG tag at the N-terminus.

\section{Cell Culture}

Human HEK-293 cells were cultured in Dulbecco's Modified Eagle Medium (DMEM) with $10 \%$ fetal bovine serum. Stable cell lines expressing the adenosine $\mathrm{A}_{1}$ or $\mathrm{A}_{2 \mathrm{~A}}$ receptor fusion proteins were generated by supplementing the media with G418 $(500 \mu \mathrm{g} / \mathrm{ml}$, final concentration). For SILAC conditions used to generate heavy $\beta \gamma$ dimers associated with the $\mathrm{A}_{1}: \mathrm{a}_{\mathrm{i} 1}$ fusion protein, DMEM Flex media (Invitrogen) was supplemented with $200 \mathrm{~g} / \mathrm{L}$ glucose, $200 \mathrm{mM}$ L-glutamine, $10 \mathrm{~g} / \mathrm{L}$ phenol red, 10\% dialyzed FBS (Invitrogen) (10,000 mw cutoff), $179.6 \mathrm{mg} / \mathrm{L}$ L-lysine: $2 \mathrm{HCl}\left[{ }^{13} \mathrm{C}_{6}\right]$ and $86.2 \mathrm{mg} / \mathrm{L} \mathrm{L}$ - arginine: $\mathrm{HCl}\left[{ }^{13} \mathrm{C}_{6}\right]$ (Cambridge Isotope Laboratories). In order to fully incorporate the heavy amino acids, cells were cultured in SILAC media for five doubling times. Cells cultured in either light or heavy media were harvested by trituration with PBS containing $5 \mathrm{mM}$ EDTA, washed with PBS, collected by centrifugation, and resuspended in buffer containing $20 \mathrm{mM}$ HEPES, $\mathrm{pH}$ 7.4, $1 \mathrm{mM}$ EGTA, and $100 \mu \mathrm{g} / \mathrm{ml}$ Pefabloc SC Plus, $2 \mu \mathrm{g} / \mathrm{ml}$ pepstatin, leupeptin, aprotinin and $20 \mu \mathrm{g} / \mathrm{ml}$ benzamidine before flash freezing and storage at $-80{ }^{\circ} \mathrm{C}$.

\section{Preparation of Enriched $\beta y$ Fraction from HEK-293 Cells}

Membranes from HEK-293 cells were collected after lysis with a $21 \mathrm{~g}$ needle and centrifugation at 53,000 RPM in a 90 Ti rotor for 45 minutes at $4{ }^{\circ} \mathrm{C}$. Buffer containing 20 $\mathrm{mM}$ Tris, pH 8.0, 1 mM EDTA, $1 \%$ cholate, $1 \mathrm{mM}$ DTT, $5 \mu \mathrm{M}$ GDP, $100 \mu \mathrm{g} / \mathrm{ml}$ Pefabloc SC Plus, $2 \mu \mathrm{g} / \mathrm{ml}$ pepstatin, leupeptin, aprotinin and $20 \mu \mathrm{g} / \mathrm{ml}$ benzamidine was used to extract $\beta \gamma$ dimers, either alone or in heterotrimeric form. The cholate extract was subjected to DEAE chromatography as described in Graber et al. (15). Fractions containing $\beta$-common immunoreactivity determined by SDS-PAGE and western blotting were pooled, concentrated, and resolved by Superose 6 size exclusion chromatography as described in McIntire et al. (11). Fractions from the Superose 6 separation containing $\beta$-common immunoreactivity were pooled, concentrated and frozen at $-80^{\circ} \mathrm{C}$.

\section{Purification of Native $\beta y$ Dimers using Receptor Fusion Proteins}

Cell pellets from approximately $3015 \mathrm{~cm}$ plates of HEK-293 cells expressing the adenosine $A_{1}: a_{i 1}$ or $A_{2 A}: a_{S}$ fusion protein were lysed by nitrogen cavitation, and membranes collected by centrifugation at 35,000 RPM in a $45 \mathrm{Ti}$ rotor for 45 minutes at $4{ }^{\circ} \mathrm{C}$. Membranes were washed with HNG buffer (20 mM HEPES, pH 7.4, $20 \mathrm{mM} \mathrm{NaCl}$ and $10 \%$ glycerol) containing $100 \mu \mathrm{g} / \mathrm{ml}$ Pefabloc SC Plus, $2 \mu \mathrm{g} / \mathrm{ml}$ pepstatin, leupeptin, aprotinin and $20 \mu \mathrm{g} /$ $\mathrm{ml}$ benzamidine, $5 \mu \mathrm{M}$ GDP, and resuspended to a volume of $10 \mathrm{mg} / \mathrm{ml}$ protein with HNG buffer containing $1 \mathrm{mM}$ EDTA, $1 \%$ n-dodecyl $\beta$-D-maltoside (DDM), $0.02 \%$ cholesteryl hemisuccinate, $100 \mu \mathrm{M}$ adenosine, $100 \mu \mathrm{g} / \mathrm{ml}$ Pefabloc SC Plus, $2 \mu \mathrm{g} / \mathrm{ml}$ pepstatin, leupeptin, aprotinin and $20 \mu \mathrm{g} / \mathrm{ml}$ benzamidine. All buffers used in the purification procedure were $0.22 \mu \mathrm{m}$ filtered, and all steps were performed at $4{ }^{\circ} \mathrm{C}$ unless otherwise noted (see Fig. 1 for flow chart of purification). After stirring for two hours, the DDM extract containing the receptor fusion protein was clarified by centrifugation as described above, and diluted to approximately $0.5 \%$ DDM with HNG buffer containing 1 mM EDTA, $100 \mu \mathrm{M}$ adenosine, $100 \mu \mathrm{g} / \mathrm{ml}$ Pefabloc SC Plus, $2 \mu \mathrm{g} / \mathrm{ml}$ pepstatin, leupeptin, aprotinin and $20 \mu \mathrm{g} / \mathrm{ml}$ benzamidine. The diluted extract was allowed to incubate with $200 \mu \mathrm{l}$ of FLAG M2 affinity resin for one hour, rocking end over end. FLAG beads were collected with a 5 $\mathrm{ml}$ centrifuge column, washed with 5 one $\mathrm{ml}$ volumes of HGN buffer containing $1 \mathrm{mM}$ EDTA (HNGE buffer), $0.1 \%$ DDM and $100 \mu \mathrm{M}$ adenosine. The column was then washed with two $1 \mathrm{ml}$ volumes of HNGE buffer containing $1 \%$ cholate and $100 \mu \mathrm{M}$ adenosine. HNGE buffer containing $100 \mu \mathrm{M}$ adenosine and $1 \%$ cholate was supplemented with $\mathrm{AlF}^{-}{ }_{4}$ (Activation Buffer) for elution of $\beta \gamma$ dimers associated with the receptor fusion 
protein; $200 \mu \mathrm{l}$ of activation buffer warmed to room temperature was added to the column and collected. The column was then capped, and a second $200 \mu \mathrm{l}$ was added and allowed to incubate for 15 minutes at room temperature in order to facilitate dissociation of $\beta \gamma$ from receptor fusion protein. After the incubation, the second volume was collected, along with 4 more $200 \mu \mathrm{l}$ volumes, and fractions containing $\beta \gamma$ dimer were pooled, concentrated in an amicon concentrator, and exchanged twice with buffer containing 20 mM HEPES, $\mathrm{pH} 7.4$, $20 \mathrm{mM} \mathrm{NaCl}, 1 \mathrm{mM}$ EDTA, $0.1 \%$ CHAPS and $1 \mathrm{mM}$ DTT. The column bound receptor fusion protein and FLAG elution buffer (HGNE buffer containing 0.1\% DDM, $100 \mu \mathrm{M}$ adenosine and $0.5 \mathrm{mg} / \mathrm{ml}$ FLAG peptide) were warmed to room temperature, and $200 \mu \mathrm{l}$ of the elution buffer was applied to the column and collected. The column was then capped, and a second $200 \mu$ l elution volume was applied and allowed to incubate for 15 minutes. The column was then uncapped, and a total of five more $200 \mu$ l elution volumes were collected to recover the receptor fusion protein.

\section{MALDI Mass Spectrometric Analysis of Intact y Subunits}

Samples were prepared based on the thin layer method described by Cadene et al. (16). Briefly, a thin layer matrix solution was prepared by diluting a saturated solution of cyanohydroxycinnamic acid in a 1:2 mixture of water:acetonitrile four fold with 2-propanol. A sample matrix solution was prepared by sonicating a cyanohydroxycinnamic acid saturated solution in a 3:1:2 mixture of formic acid:water:acetonitrile for 10 minutes, followed by centrifugation. The thin layer matrix was prepared by applying 10-20 $\mu 1$ of thin layer matrix solution on a plate and allowing it to spread. When only traces of solvent were remaining, the plate was gently wiped to leave only a thin film of matrix. The sample matrix solution was used to dilute the purified $\beta \gamma$ samples 20 fold; within 10 minutes, $0.5 \mu \mathrm{l}$ was loaded on the plate containing the thin layer, allowed to dry and washed with $2 \mu 1$ of $0.1 \%$ TFA. Samples were then analyzed on a Bruker MicroFlex MALDI mass spectrometer in linear mode using the manufacturer's standard settings and collecting 200 shots.

\section{SDS-PAGE and Western Blotting}

Prior to gel electrophoresis, samples were incubated with 6x sample buffer at room temperature for one hour without boiling. Proteins were separated using $12 \%$ polyacrylamide gels, and visualized by staining with silver or Coomassie blue; alternatively, gels were transferred to nitrocellulose for western blotting with a $\beta$-common (sc-378, Santa Cruz) or a-common (NEI-800, DuPont NEN) antibody. Polyacrylamide gels used for generation of samples for mass spectrometric analysis were prepared by $0.22 \mathrm{~m}$ filtration of the separating and stacking solutions, as well as the running buffer; this step is important for removal of common protein contaminants, such as keratin, that can obscure the detection of sample proteins. Gels were stained in a 0.1\% Coomassie Brilliant blue solution of 45:45:10 methanol:water:acetic acid, followed by destaining in a 45:45:10 methanol:water:acetic acid solution. Once protein bands were adequately visualized, gels were stored in a $10 \%$ acetic acid solution. The $\beta$ protein, which separates from $\gamma$ during SDS-PAGE, has an electrophoretic mobility of approximately $36 \mathrm{kDa}$, while the $\gamma$ protein is present at the dye front. These portions of the gel were excised in order to recover protein for mass spectrometric analysis.

\section{Tryptic Digestion of Gel Bands and LC/MS/MS Analysis}

Gel pieces were transferred to siliconized tubes and washed and destained in $200 \mu 150 \%$ methanol overnight. The gel pieces were dehydrated in acetonitrile, rehydrated in $30 \mu \mathrm{L}$ of $10 \mathrm{mM}$ dithiolthreitol in $0.1 \mathrm{M}$ ammonium bicarbonate and reduced at room temperature for $0.5 \mathrm{~h}$. The DTT solution was removed and the sample alkylated in $30 \mu \mathrm{L} 50 \mathrm{mM}$ iodoacetamide in $0.1 \mathrm{M}$ ammonium bicarbonate at room temperature for $0.5 \mathrm{~h}$. The reagent was removed and the gel pieces dehydrated in $100 \mu l$ acetonitrile. The acetonitrile was 
removed and the gel pieces rehydrated in $100 \mu 10.1 \mathrm{M}$ ammonium bicarbonate. The pieces were dehydrated in $100 \mu \mathrm{l}$ acetonitrile, the acetonitrile removed and the pieces completely dried by vacuum centrifugation. The gel pieces were rehydrated in $20 \mathrm{ng} / \mu \mathrm{l}$ trypsin in 50 $\mathrm{mM}$ ammonium bicarbonate on ice for $10 \mathrm{~min}$. Any excess enzyme solution was removed and $20 \mu \mathrm{L} 50 \mathrm{mM}$ ammonium bicarbonate added. The sample was digested overnight at 37 ${ }^{\circ} \mathrm{C}$ and the peptides formed extracted from the polyacrylamide in two $30 \mu \mathrm{l}$ aliquots of $50 \%$ acetonitrile $/ 5 \%$ formic acid. These extracts were combined and evaporated to $15 \mu \mathrm{l}$ for MS analysis.

The LC-MS system consisted of a Thermo Electron LTQ Orbitrap XL mass spectrometer system with a Protana nanospray ion source interfaced to a self-packed $8 \mathrm{~cm} \times 75 \mathrm{um}$ id Phenomenex Jupiter 10 um C18 reversed-phase capillary column. $7.5 \mu \mathrm{L}$ volumes of the extract were injected and the peptides eluted from the column by an acetonitrile/ $/ 0.1 \mathrm{M}$ acetic acid gradient at a flow rate of $0.4 \mu \mathrm{l} / \mathrm{min}$ over 1 hour. The nanospray ion source was operated at $2.5 \mathrm{kV}$. The digest was analyzed by acquiring a full scan mass spectrum using Fourier-transform ion cyclotron resonance at 100k resolving power to determine peptide molecular weights followed by 10 product ion spectra in the ion trap to determine amino acid sequence in sequential scans. This mode of analysis produces approximately 10,000 $\mathrm{ms} / \mathrm{ms}$ spectra of ions ranging in abundance over several orders of magnitude. The data were analyzed by database searching using the Sequest algorithm against Human International Protein Index (v3.66).

\section{Determination of Ratios of Heavy and Light Peptides}

Peptide spectra putatively identified by Sequest as belonging to $G$ protein $\gamma$ or $\beta$ isoforms were manually verified. H:L peptide ratios were calculated using areas obtained from QualBrowser (Xcalibur 2.1) for the monoisotopic m/z (+/- 0.01Da) for the heavy and light forms. The H:L ratio for each protein was obtained by taking the average peptide ratio for all peptides observed for a particular isoform.

\section{Calculation of Protein Concentration}

For $A_{1}: a_{i 1}$ fusion protein $\beta \gamma$ dimers purified from HEK-293 cells cultured in media containing $\left[{ }^{13} \mathrm{C}_{6}\right]$ Arg and $\left[{ }^{13} \mathrm{C}_{6}\right]$ Lys, protein concentration was determined by western blotting with the sc-378 $\beta$-common antibody (Santa Cruz), against a standard curve of purified recombinant $\beta \gamma$ dimer from Sf9 cells. For $\beta$ isoform quantitation by mass spectrometry, purified recombinant $\beta_{1} \gamma_{2}, \beta_{2} \gamma_{2}$ and $\beta_{4} \gamma_{2}$ dimers from Sf9 cells were each added to the $A_{1}: a_{i 1}$ fusion protein $\beta \gamma$ dimers at a 1:10 molar ratio. For $\gamma$ isoform quantitation, purified recombinant $\beta_{1} \gamma_{2}, \beta_{1} \gamma_{5}, \beta_{1} \gamma_{7}, \beta_{1} \gamma_{10}, \beta_{1} \gamma_{11}$ and $\beta_{1} \gamma_{12}$ dimers from Sf9 cells were also each added at a 1:10 ratio. The combined samples were separated by SDS-PAGE (Fig. 1) and processed according to the procedure outlined above in SDS-PAGE and Western Blotting and Tryptic Digestion of Gel Bands and LC/MS/MS Analysis.

Typically, several peptides from each $\beta$ or $\gamma$ isoform (see Table 3) produced ion pairs that were used to determine an average peak area ratio between heavy and light ion traces (H:L). Expression of $\beta$ and $\gamma$ isoforms as $\mu \mathrm{g} / \mu \mathrm{l}$ of sample was determined by multiplying the average (H:L) ratio for each isoform by the $\gamma$ of each standard isoform added. The amount of Sf $9 \gamma$ isoform added in a standard was determined indirectly as a function of $\beta$ concentration, assuming a 1:1 $\beta: \gamma$ ratio. In experiments comparing $\beta \gamma$ dimers between fusion proteins, or between the $A_{1}: a_{i 1}$ fusion protein and the enriched HEK-293 $\beta \gamma$ fraction, the known heavy $\beta$ and $\gamma$ concentrations from the $A_{1}: a_{i 1}$ fusion protein were used along with the $\mathrm{H}: \mathrm{L}$ ratios to determine the relative amounts of light $\beta$ and $\gamma$ isoforms associated with the $A_{2 A}: a_{S}$ fusion protein, or present in the enriched $\beta \gamma$ fraction from HEK-293 cells. In order to normalize the relative levels of $\beta$ and $\gamma$ isoforms present, each $\beta$ and $\gamma$ isoform 
was expressed as a percent of the total $\beta$ and $\gamma$ protein quantified, respectively, for each sample.

\section{Statistical Analysis}

$\mathrm{H}: \mathrm{L}$ ratios were first analyzed for variability, and ratios that were greater than two standard deviations from the mean of data sets containing at least five values were excluded from further analysis. $\mathrm{N}$ values higher than the number of peptides observed (Table $3, \mathrm{~A}_{1}: \mathrm{a}_{\mathrm{i} 1}$ vs enriched HEK-293 $\beta \gamma$ fraction) occur when several charge states of the same peptide generate unique H:L ratios. Prior to pooling data from separate experiments, H:L ratios were converted into moles of $\beta$ or $\gamma$, and then expressed as percent of total moles $\beta$ or $\gamma$ detected. In order to determine statistical significance, data sets were compared using the unpaired $t$ test in GraphPad Prism ${ }^{\circledR} 5$ to calculate two-tailed p-values.

\section{Materials}

Reagents for Sf9 cell culture and purification of $\beta \gamma$ dimers have been described previously (17-20). GDP, CHS, adenosine, HEPES and anti-FLAG M2 agarose from Sigma; DDM from MP Biochemicals; FLAG peptide was synthesized at the University of Virginia Biomolecular Research Facility; CHAPS from Roche Molecular Biochemicals; 10\% Genapol C-100 from CalBiochem; Ni ${ }^{2+}$-NTA Superflow resin from Qiagen; centricon 30 concentrators from Millipore; Superose ${ }^{\mathrm{TM}} 6 \mathrm{HR}$ 10/30 column from Pharmacia; all other materials were of the highest available purity. Mass spectrometric analysis of peptides was performed at the W.M. Keck Biomedical Mass Spectrometry Laboratory.

\section{RESULTS}

\section{Methodology}

A graphical overview of the process for the isolation and biochemical characterization of native $\beta \gamma$ dimers from cells is provided in figure 1 . The scheme for $\beta \gamma$ purification from a receptor: $a: \beta \gamma$ complex after expression of epitope tagged adenosine receptor: $a$ fusion protein in cells cultured in "heavy" SILAC media to introduce $\left[{ }^{13} \mathrm{C}\right]$ labeled Lys and Arg into cellular proteins is presented in figure 1A. This general scheme could be used for any combination of receptor and $\mathrm{a}$ engineered in a fusion protein construct. Figure 1B illustrates recombinant $\beta \gamma$ dimers purified from Sf9 cells cultured in normal or "light" media. The $\beta \gamma$ dimers containing different $\beta$ isoforms (stained with Coomassie blue, Fig. 1B, above) and different $\gamma$ isoforms (stained with silver, Fig. 1B, below) were used to quantify $\beta$ and $\gamma$ isoforms isolated from HEK-293 cells in figure 1A. A known amount of light $\beta \gamma$ standard is combined with the native mixture of heavy $\beta \gamma$ derived from the receptor fusion protein for quantitative analysis by mass spectrometry. Figure $1 \mathrm{C}$ illustrates the purity of the combined $\beta \gamma$ dimers from both sources after separation by SDS-PAGE and staining with Coomassie blue. The $\beta$ and $\gamma$ proteins from the gel in figure 1C (see boxes) are excised, digested with trypsin and analyzed by LC/MS/MS as described in Experimental Procedures.

\section{Analysis of $\beta$ and $y$ mRNA Transcript Levels in HEK-293 Cells}

Although the main focus of this study was to characterize the $\beta$ and $\gamma$ isoforms at the protein level, it was also important to correlate $\beta$ and $\gamma$ protein with mRNA levels. Validated human PCR primers designed to target specific $\beta$ and $\gamma$ isoforms are listed in Table 1; all primers were validated by sequence verification of the amplicon, with the exception of the $\gamma_{2}$ primers, which specifically recognized a plasmid containing the target sequence. Since this study examined the $\beta \gamma$ dimers from HEK-293 cells, the $\beta_{3}$ and $\beta_{5}$ primers, as well as the $\gamma_{1}$, $\gamma_{3}, \gamma_{8}, \gamma_{9}$ and $\gamma_{13}$ primers were excluded from this analysis, as these isoforms were not observed experimentally at the protein level $(21 ; 22)$, and thus do not appear to have a 
prominent role in HEK-293 cell $\gamma$ protein signaling. Of the $\beta$ isoforms, $\beta_{2}$ was the most abundant, with transcript levels over tenfold higher than $\beta_{1}$ or $\beta_{4}$ in wild type cells (Fig. 2, white bars). The $\gamma_{4}, \gamma_{5}$ and $\gamma_{12}$ isoforms were all transcribed at high levels in wild type cells; however, transcripts for $\gamma_{2}, \gamma_{7}, \gamma_{10}$ and $\gamma_{11}$ were also detected (Fig. 2, white bars). $\beta$ and $\gamma$ mRNA levels were also compared to HEK-293 cell lines expressing the adenosine $A_{1}: a_{i 1}$ fusion protein (Fig. 2, black bars) or the adenosine $A_{2 A}: a_{S}$ fusion protein (Fig. 2, hatched bars) to control for possible changes in transcription caused by fusion protein expression. There were no significant differences in $\beta$ or $\gamma$ transcript levels between the adenosine $\mathrm{A}_{1}$ and $\mathrm{A}_{2 \mathrm{~A}}$ receptor fusion protein stable cell lines; in addition, there were no differences in $\beta$ or $\gamma$ mRNA between the wild type HEK-293 cells and the cell line expressing the $A_{1}: a_{i 1}$ fusion protein. However, the HEK-293 cell line expressing the $A_{2 A}: a_{S}$ fusion protein displayed an approximately eight-fold increase in $\beta_{1}$ mRNA, increasing from $0.03 \%$ in wild type cells to $0.20 \%$ in the $A_{2 A}: a_{S}$ stable cell line (Fig. 2). Further, there was a three-fold increase in $\beta_{4}$ mRNA, from $0.4 \%$ in wild type cells to $1.25 \%$ in the $A_{2 A}: a_{S}$ stable cell line (Fig. 2).

\section{Purification of Native $\beta y$ Dimers Associated with the Adenosine $A_{1}: \alpha_{i 1}$ Fusion Protein Expressed in HEK-293 Cells}

The high affinity agonist binding state of a receptor occurs when it is bound to heterotrimeric $\gamma$ protein, which makes agonist binding a useful parameter for measuring the interaction between receptor and $\gamma$ protein. The fusion of $a_{i 1}$ onto the $\mathrm{C}$-terminus of the adenosine $\mathrm{A}_{1}$ receptor did not interfere with the ability of the receptor to interact with the complete heterotrimeric $\gamma$ protein, as measured by high affinity agonist binding (23). Thus the fact that the $A_{1}: a_{i 1}$ fusion protein was functionally similar to the analogous non-fused proteins (23) made it a natural initial choice for the examination of interactions between the adenosine $A_{1}$ receptor, $\alpha_{i 1}$ and $\beta$ and $\gamma$ isoforms. Figure 3 illustrates the purification of native HEK-293 $\beta \gamma$ dimers from the 6HIS/FLAG tagged $\mathrm{A}_{1}: \mathrm{a}_{\mathrm{i} 1}$ fusion protein; the $\beta$ subunit at $36 \mathrm{kDa}$ can clearly be seen in both the silver stained gel and the $\beta$-common western blot ( $\mathrm{AlF}_{4}{ }^{-}$elutions 2 and 3, Fig. 3). Figure $1 \mathrm{C}$ demonstrates the purity of native HEK-293 $\beta \gamma$ dimers combined with Sf9 purified $\beta \gamma$ dimers after staining with Coomassie blue. The $A_{1}: a_{i 1}$ fusion protein can also be recovered by elution with FLAG peptide; the expected electrophoretic mobility of the receptor fusion protein is approximately $80 \mathrm{kDa}$. In agreement with this, FLAG immunoreactivity was observed in the FLAG elution fractions of the western blot between the 75 and $100 \mathrm{kDa}$ molecular weight standards (Fig. 3, FLAG blot, elutions 2-4). The faint visualization of the receptor fusion protein in the silver stained gel of figure 3 may be due to glycosylation induced band broadening of the fusion protein, or differential protein staining with silver. Similar results were observed for the purification of $\beta \gamma$ from the $A_{2 A}: a_{S}$ fusion protein (data not shown).

\section{MALDI Mass Spectrometric Analysis of Intact y Subunits}

Figure 4A displays a mass spectrum of purified $\beta_{1} \gamma_{5}$ from Sf9 cells using MALDI mass spectrometry, a technique which is able to ionize intact $\gamma$ subunits in the $[\mathrm{M}+\mathrm{H}]+$ charge state. The largest peak at approximately $7160 \mathrm{~m} / \mathrm{z}$ (Fig. 4A, left dashed line) corresponds to the predicted mass of the $\gamma_{5}$ subunit which undergoes the conventional posttranslational processing of prenylation, cleavage of the $\mathrm{C}$-terminal three amino acids, and methylation of the prenylated cysteine (5). At the higher $\mathrm{m} / \mathrm{z}$ of 7501.9 (Fig. 4A, middle dashed line), a smaller peak corresponds to the predicted mass (7501.3) of the $\gamma_{5}$ lacking proteolytic cleavage of the three C-terminal SFL residues (22). In contrast, the largest peak at $\mathrm{m} / \mathrm{z}$ of 7501.7 in the mass spectrum for $\beta \gamma$ purified from the $A_{1}: a_{i 1}$ fusion protein expressed in HEK-293 cells (Fig. 4B, middle dashed line) corresponds to a geranylgeranylated $\gamma_{5}$ lacking proteolytic cleavage of the three C-terminal SFL residues with a predicted mass of 7501.3. Similar results were observed for the $\beta \gamma$ purified from the $A_{2 A}: a_{S}$ fusion protein (Fig. $4 C$, 
middle dashed line), with the experimental $\mathrm{m} / \mathrm{z}$ of 7504.0 in good agreement with the predicted mass of 7501.3. The mass spectrum for the "heavy" $\beta \gamma$ purified from the $A_{1}: a_{i 1}$ fusion protein expressed in HEK-293 cells under SILAC conditions was observed to have a peak (Fig. 4D, right dashed line) that was approximately 45 Daltons higher than the major peak in figure $4 \mathrm{~B}$. This peak with an $\mathrm{m} / \mathrm{z}$ of 7546.4 was in agreement with the predicted mass of 7549.3 for a geranylgeranylated $\gamma_{5}$ subunit lacking proteolytic cleavage of the three C-terminal SFL residues, in which all of the arginines and lysines have been replaced with $\left[{ }^{13} \mathrm{C}_{6}\right]$ Arg and $\left[{ }^{13} \mathrm{C}_{6}\right]$ Lys, respectively. The experimental implications of differential posttranslational modification (24) are illustrated in the silver stained gel of purified $\gamma$ subunits in figure 1, where significant heterogeneity in electrophoretic mobility of different $\gamma$ isoforms was observed under the separating conditions (12\% SDS-PAGE).

\section{ESI-MS/MS Analysis of Modifications to y Isoforms}

Differential N-terminal processing was also observed in the MS/MS analysis of peptides from $\gamma$ isoforms. Table 2 lists all of the $\gamma$ isoforms characterized in this study, with the $\mathrm{N}$ terminal sequence translated from the open reading frame of each $\gamma$ gene, and the $\mathrm{N}$ terminal structure for each $\gamma$ isoform purified from the $A_{1}: a_{i 1}$ and $A_{2 A}: a_{S}$ fusion proteins as determined by mass spectrometry. Although levels of the $\gamma_{4}$ isoform were not quantified, data from the mass spectrometric analysis still allowed qualitative characterization of posttranslational processing of this isoform. With the exception of $\gamma_{4}$, all the $\gamma$ isoforms for which $\mathrm{N}$-terminal peptides were observed $\left(\gamma_{2}, \gamma_{5}, \gamma_{7}\right.$ and $\left.\gamma_{10}\right)$ had undergone cleavage of the $\mathrm{N}$-terminal methionine, followed by acetylation (Table 2). The presence of the $\mathrm{N}$ terminal methionine in $\gamma_{4}$ can be accounted for by the lysine at position 2 (Table 2), which has been reported to provide a poor binding environment for methionine aminopeptidase (25). N-terminal acetylation of proteins containing a Met-Lys at positions 1 and 2 has been reported to be variable in humans (26). A study of bovine brain derived $\gamma_{3}$, which also contains an $\mathrm{N}$-terminal Met-Lys motif, and is thus expected to retain the $\mathrm{N}$-terminal methionine, found more than half of the protein to be acetylated at the N-terminal methionine (24). Although the characterization of $\mathrm{N}$-terminal processing of $\gamma$ isoforms in this study is not quantitative, only unacetylated $\mathrm{N}$-terminal peptides were detected for $\gamma_{4}$ (Table 2). The absence of $\mathrm{N}$-terminal peptides for $\gamma_{11}$ was probably due to the low abundance of this isoform, and the Lys at position 4 of $\gamma_{12}$ (Table 2) likely resulted in a tryptic N-terminal peptide that was too small for successful analysis. Other studies, however, have reported that the $\gamma_{12}$ isoform undergoes cleavage of the N-terminal methionine, followed by acetylation of the resulting $\mathrm{N}$-terminal serine (24). This differential processing of the $\mathrm{N}$-termini of $\gamma$ isoforms implies a point of functional regulation in the $\gamma$ subunit, which is discussed below.

\section{Quantitative Mass Spectrometric Analysis of $\beta y$ Purified from the Adenosine $A_{1}: \alpha_{i 1}$ Fusion Protein}

The use of SILAC allows the simultaneous biochemical processing of chemically identical heavy and light proteins and peptides, which can be differentiated and measured in a mass spectrometer as heavy and light ion pairs. The ratio of the signal intensity of the ion pairs can thus be translated into quantitative information about the proteins in the sample. Ion pairs from the LC MS/MS analysis of heavy $\beta \gamma$ tryptic peptides from SILAC treated Adenosine $A_{1}: a_{i 1}$ fusion protein and light $\beta \gamma$ tryptic peptides from Sf9 purified $\beta \gamma$ were identified and quantified by mass spectrometry.

The use of SILAC technology enables the characterization of heavy and light ion pairs by mass spectrometry over a wide dynamic range. Figure 5A illustrates the ion pair for the peptide KVVQQLR from the abundant $\gamma_{5}$ isoform. Since the peptide has both a lysine and an arginine, the net mass difference between the heavy and light peptides is 12 Daltons; 
however, since the ions have a charge of $2+$, the $\mathrm{m} / \mathrm{z}$ difference is only 6 . The inset (Fig. 5A) illustrates the relationship between the retention time by HPLC and the ion traces for the monoisotopic heavy and light ions indicated by arrows (Fig. 5). Since peptides with the heavy isotopes are chemically identical to their light counterparts, all ion pairs will have identical retention times and thus will be affected equally by any ionization influencing artifacts introduced by the sample. The ratio of the signal intensities of the ion current peaks (Fig. 5A, inset) for the heavy and light peptides in the ion pair is used to quantify protein levels. An example of an ion pair from the less abundant $\gamma_{11}$ comes from the peptide SGEDPLVK (Fig. 5B); in the large spectrum, only the light ion is visible. However, when the part of the $\mathrm{x}$-axis containing the heavy ion is magnified 100x (Fig. 5B, grey box in inset), the heavy ion becomes visible. The SGEDPLVK ion is also $[\mathrm{M}+\mathrm{H}] 2+$, however, since there is only one amino acid that can be exchanged for a heavy isotope, the net mass change is only 6 Daltons and the $\mathrm{m} / \mathrm{z}$ difference is 3 . Table 3 contains a complete list of all the peptides that produced ion pairs used to quantify protein levels of $\gamma$ isoforms associated with the $\mathrm{A}_{1}: \mathrm{a}_{\mathrm{i} 1}$ fusion protein.

Ion pairs for $\beta$ isoforms were also examined, and figure $6 \mathrm{~A}$ illustrates an example from the ELAGHTGYLSCCR peptide from the most abundant $\beta_{1}$ isoform. A peptide from the least abundant $\beta_{4}$, TFVSGACDASSK, yields an ion pair that is illustrated in figure $6 \mathrm{~B}$ with a $2+$ charge state. All of the peptides from which ion pairs were observed for the quantification of $\beta$ isoforms associated with the $A_{1}: a_{i 1}$ fusion protein are listed in Table 3 .

The protein concentration from the known Sf9 $\beta \gamma$ standards and the ratios of the heavy and light ion pairs were used to calculate the moles of each $\beta$ and $\gamma$ isoform purified from the $\mathrm{A}_{1}: \mathrm{a}_{\mathrm{i} 1}$ fusion protein. After expressing each $\beta$ and $\gamma$ isoform as a percent of the total $\beta$ and $\gamma$ protein observed, respectively, levels of each $\beta$ isoform (Fig. 7A) and $\gamma$ isoform (Fig. 7B) purified from the $A_{1}: a_{i 1}$ fusion protein were compared to every other $\beta$ and $\gamma$ isoform member (respectively) for differences in the percentage levels. All of the $\beta$ isoforms were different from each other at the $\mathrm{p}<0.001$ level (Fig. 7A), with $\beta_{1}$ over 12 -fold more abundant than $\beta_{4}$ (see Fig. 7C for bar graph expression of data in Fig. 7A). Significant differences were observed among many of the $\gamma$ isoforms; notably, $\gamma_{5}$ was estimated to be $78 \%$ of total $\gamma$ isoforms, while $\gamma_{11}$ was only $0.03 \%$ of total $\gamma$ isoforms (Fig. 7B). Although $\gamma_{5}$ was the most abundant $\gamma$ isoform, $\gamma_{2}, \gamma_{7}, \gamma_{10}$ and $\gamma_{12}$ all presented between 2-12\% of total $\gamma$ isoforms (Fig. 7C). Data in figure 7B are expressed in bar graph format in figure 7D.

\section{Quantitation of $\beta$ and $y$ Isoforms in HEK-293 Cells and Associated with the $A_{2 A}: \alpha_{S}$ Receptor Fusion Protein}

One important question arising from quantitation of the $\beta$ and $\gamma$ isoform composition of the $A_{1}: a_{i 1}$ fusion protein is the relationship of the $A_{1}: a_{i 1} \beta \gamma$ profile to that of another receptor, or to the $\beta \gamma$ profile in the whole cell. Enrichment of the $\beta \gamma$ fraction in HEK-293 cells was necessary to reduce background protein signal and increase the strength of $\beta$ and $\gamma$ peptide signals in the mass spectrometric analysis. Protein concentration of the enriched $\beta \gamma$ fraction from HEK-293 cells based on quantitative western blotting was $7.9 \mathrm{ng} \beta / \mu \mathrm{g}$ protein (sc-378, Santa Cruz) and $3.1 \mathrm{ng} \alpha / \mu \mathrm{g}$ protein (NEI-800, DuPont NEN); thus, the enriched $\beta \gamma$ fraction likely contained both free $\beta \gamma$ and heterotrimeric $\gamma$ protein. The $A_{2 A}: a_{S}$ fusion protein was chosen for comparison purposes as a member of the same receptor family with distinctly different $\mathrm{Ga}$ coupling preferences. For the experimental comparisons, heavy $\beta \gamma$ purified from the $A_{1}: a_{i 1}$ fusion protein was added to a similar amount of light $\beta \gamma$ purified from the $A_{2 A}: a_{S}$ fusion protein, and to the enriched $\beta \gamma$ fraction from HEK-293 cells. The samples were then separated by SDS-PAGE, stained with Coomassie blue, and the gel bands containing the heavy and light $\beta$ isoforms, and the heavy and light $\gamma$ isoforms were excised and analyzed as described in Materials and Methods. 
Using the heavy $\beta \gamma$ dimers purified from $A_{1}: a_{i 1}$ as standards, $\beta$ and $\gamma$ isoform levels in both the whole cell and specifically associated with $A_{2 A}: a_{S}$ were calculated (See Table 3 for list of peptides used to determine $\mathrm{H}: \mathrm{L}$ ratios). Figure 8 illustrates that the $\mathrm{A}_{2 \mathrm{~A}}: \mathrm{a}_{\mathrm{S}}$ fusion protein bound $\sim 30 \%$ more $\beta_{4}$ ( $6.8 \%$ of total $\beta$ ) compared to the $A_{1}: a_{i 1}$ fusion protein (5.3\% of total $\beta$ ). Further, the $A_{1}: a_{i 1}$ fusion protein contained $\sim 40 \%$ higher levels of $\beta_{4}$ than the enriched $\beta \gamma$ fraction from HEK-293 cells (Fig. 8: 5.3\% vs 3.7\% of total $\beta$ ), and the $A_{2 A}: a_{S}$ fusion protein contained $\sim 80 \%$ higher levels of $\beta_{4}$ than the enriched $\beta \gamma$ fraction (Fig. 8: $6.8 \%$ vs $3.7 \%$ of total $\beta$ ). Differences in $\beta_{1}$ and $\beta_{2}$ levels were not significantly different among $A_{1}: a_{i 1}, A_{2 A}: a_{S}$, or total HEK-293 $\beta \gamma$; however, levels of $\beta_{2}$ were trending lower in both $A_{1}: a_{i 1}$ and $A_{2 A}: a_{S}$ compared to total HEK-293 $\beta \gamma$ (Fig. 8), offsetting the higher levels of $\beta_{4}$ in both fusion proteins. No differences were observed in types of $\gamma$ isoforms between $A_{1}: a_{i 1}$ and $A_{2 A}: a_{S}$; however, the $A_{1}: a_{i 1}$ and $A_{2 A}: a_{S}$ fusion proteins contained $25 \%$ and $21 \%$ higher levels of $\gamma_{5}$, respectively, than total HEK-293 cell $\beta \gamma$. These higher levels of $\gamma_{5}$ were offset by lower levels of $\gamma_{2}\left(\mathrm{~A}_{1}: \mathrm{a}_{\mathrm{i} 1}: 41 \% \Delta ; \mathrm{A}_{2 \mathrm{~A}}: \mathrm{a}_{\mathrm{S}}: 40 \% \Delta\right) \gamma_{10}\left(\mathrm{~A}_{1}: \mathrm{a}_{\mathrm{i} 1}: 61 \% \Delta\right.$; $\left.\mathrm{A}_{2 \mathrm{~A}}: \mathrm{a}_{\mathrm{S}}: 54 \% \Delta\right)$ and $\gamma_{12}\left(\mathrm{~A}_{1}: \mathrm{a}_{\mathrm{i1}}: 36 \% \Delta ; \mathrm{A}_{2 \mathrm{~A}}: \mathrm{a}_{\mathrm{S}}: 29 \% \Delta\right)$ compared to total HEK-293 cell $\beta \gamma$ (Fig. 9). Though not significantly different, the $\gamma_{7}$ isoform appeared to also trend lower in $A_{1}: a_{i 1}$ and $A_{2 A}: a_{S}$ compared to total HEK-293 cell $\beta \gamma$ (Fig. 9).

Numerical values (+/-SEM) for $\beta$ and $\gamma$ protein levels associated with the $A_{2 A}: a_{S}$ the fusion protein and the enriched $\beta \gamma$ fraction from HEK-293 cells are reported in Table 4. Interestingly, levels of mRNA detected for $\beta$ isoforms (Fig. 2) did not correlate with $\beta$ protein levels in the HEK-293 enriched $\beta \gamma$ fraction (Fig. 8). Whereas $\beta_{2}$ mRNA was tenfold higher than $\beta_{1}$ mRNA, $\beta_{1}$ protein was actually two-fold higher than $\beta_{2}$ protein, suggesting that the $\beta_{1}$ protein is relatively long lived in the cell. In contrast to the $\beta$ isoform, protein levels for $\gamma$ isoforms (Fig. 9) correlated roughly with the mRNA detected by QPCR (Fig. 2), suggesting that the $\gamma_{4}$ isoform (which was not quantified) is moderately expressed in HEK-293 cells. These discrepancies suggest that QPCR data should be interpreted with caution, and if at all possible, verified with quantitative data at the protein level.

\section{$\beta: y$ Ratios Associated with $A_{1}: \alpha_{i 1}$ and $A_{2 A}: \alpha_{S}$ Receptor Fusion Proteins and Enriched $\beta Y$ Fraction from HEK-293 Cells}

Quantitation of $\beta$ and $\gamma$ isoforms allowed examination of the ratio between $\beta$ and $\gamma$ subunits in dimers purified from the $A_{1}: a_{i 1}$ and $A_{2 A}: a_{S}$ receptor fusion proteins, as well as in the enriched $\beta \gamma$ fraction from HEK-293 cells. This was done by dividing the total moles of $\gamma$ isoforms in a sample by the total moles of $\beta$ isoforms in a sample. In theory there is a 1:1 ratio of $\beta: \gamma$ subunits in a given sample of purified $\beta \gamma$ dimer. Using quantitative values from this study, there were 0.69 and 0.72 moles of $\gamma$ for every mole of $\beta$ in the $\beta \gamma$ dimers purified from the $A_{1}: a_{i 1}$ and $A_{2 A}: a_{S}$ receptor fusion proteins, respectively; similarly, the ratio of $\gamma$ to $\beta$ in the enriched HEK-293 cell fraction was 0.71 . This was somewhat expected, as $\gamma_{4}$ was not included in the total estimates of $\gamma$ protein for each receptor fusion protein. Furthermore, reports of instability of $\beta \gamma$ dimers containing $\gamma_{11}(11 ; 27)$ suggest that $\gamma_{11}$ levels in the analysis may be underestimates of the actual level of $\gamma_{11}$ present prior to the steps used to either purify the receptor-G protein complex or enrich the fraction of $\beta \gamma$ from HEK-293 cells. The theoretical $\beta \gamma$ ratio of 1:1 is an important issue in the choice of Sf9 $\beta \gamma$ standards, as the $\gamma$ concentration was calculated indirectly from $\beta$. Most cases of unstable $\beta \gamma$ dimer combinations involve $\beta_{2}, \beta_{3}, \beta_{4}$ or $\beta_{5}$ (see review (5)); for this reason, $\beta_{1}$ was expressed with different $\gamma$ isoforms for the generation of recombinant $\beta \gamma$ standards used to calculate $\gamma$ protein levels.

The preference of adenosine $A_{1}$ and $A_{2 A}$ receptors for $\beta_{4}$ and $\gamma_{5}$ isoforms is in agreement with previous reconstitution studies that demonstrated that $\beta_{2} \gamma_{2}$ and $\beta_{4} \gamma_{2}$ were more efficient than $\beta_{1} \gamma_{2}$ at coupling $G_{S}$ a to the adenosine $A_{2 A}$ receptor (28). This study refines that work by identifying the $\beta_{4}$ isoform as the preferred binding partner of the two fusion 
proteins. The previous work is also expanded through the demonstration that the adenosine $A_{1}$ and $A_{2 A}$ receptors share a preference for the $\gamma_{5}$ isoform. Together, these studies suggest that in the case of adenosine receptors, binding specific $\beta \gamma$ dimer combinations is more strongly determined by the receptor family than the identity of Ga subunit that binds a particular receptor isoform.

\section{DISCUSSION}

G protein $\beta \gamma$ dimers exist at the beginning of a signaling event as part of a receptor:Ga $\beta \gamma$ ternary complex (29), with $\beta \gamma$ binding to both receptor and Ga subunit (11). The crystal structure of a heterotrimeric $\mathrm{G}$ protein provided evidence that binding sites for $\beta \gamma$ on $\mathrm{Ga}$ family members are highly conserved (30), and few accounts of specificity, such as between $\mathrm{G}_{\mathrm{q}} \alpha$ and $\beta_{5}$ (17), have been reported. Broad diversity in both potential $\beta \gamma$ dimer combinations (11) and G protein coupled receptor isoforms (31) suggest that receptor, or possibly both receptor and $\mathrm{Ga}$, influence the composition of $\beta$ and $\gamma$ isoforms in a receptor$\mathrm{G}$ protein complex. Understanding preferences of specific receptors for particular combinations of $a, \beta$ and $\gamma$ will help to elucidate the structural determinants that favor these combinations.

Two limitations had to be overcome to successfully quantify $\beta$ and $\gamma$ dimers associated with specific receptors. The first limitation concerned the isolation of $\beta \gamma$ in sufficient quantity and purity for biochemical analysis. Receptors have been precipitated with associated $\mathrm{G}$ proteins, however, affinity and stoichiometry between $\mathrm{G}$ protein and receptor can be variable (32), and often not adequate for biochemical analysis (unpublished observation). Thus, a receptor fusion protein strategy was employed in order to preserve the interactions among $\beta \gamma$, receptor and $\mathrm{Ga}$ during purification of the complex (Fig. 1). This approach allows a more consistent purification, and would likely be applicable to any receptor-a combination.

The second limitation involves the availability of immunological reagents for characterizing $\beta$ and $\gamma$ isoforms. Many of the antibodies available do not have sufficient sensitivity or specificity to distinguish between isoforms, and thus are not quantitative. Mass spectrometry in conjunction with SILAC was chosen as an innovative and powerful approach to quantify $\beta$ and $\gamma$ isoforms for several reasons: 1) Obviation of the need for specific antibodies; 2) Femtomole sensitivity; 3) Linearity of heavy:light ion ratios at all signal strengths; 4) Absolute specificity with respect to protein isoform and species; 5) Ability to characterize covalent modifications of protein isoforms.

Posttranslational modification of proteins is critical to understand because it can have the effect of increasing the functional heterogeneity of a protein. Covalent modifications of $\gamma$ isoforms were probed by both MALDI and ESI mass spectrometry. MALDI mass spectrometry was able to initially characterize the modification state of the $\gamma_{5}$ subunits from $\beta \gamma$ populations purified from both adenosine receptor fusion proteins in HEK-293 cells. In contrast to the $\gamma_{5}$ protein observed from the $\beta_{1} \gamma_{5}$ dimer purified from Sf9 cells (Fig. 4A), and other mammalian $\gamma$ isoforms which appear to exist predominantly in the prenylated and C-terminally processed state (24), the $\gamma_{5}$ protein associated with both $A_{1}: a_{i 1}$ and $A_{2 A}: a_{S}$ receptor fusion proteins was mostly prenylated without $\mathrm{C}$-terminal proteolytic processing. This pattern of processing for $\gamma_{5}$ is in agreement with the results reported by Kilpatrick et al. (22), which the authors suggest may be related to protein-protein interactions.

ESI-MS/MS analysis was also able to reveal the N-terminal modification state of many of the $\gamma$ isoform derived peptides identified in this study. The significance of differential Nterminal acetylation of $\gamma$ isoforms was emphasized by a recent study in Saccharomyces 
cerevisiae that suggested $\mathrm{N}$-terminal acetylation is a degradation signal in the $\mathrm{N}$-end rule pathway (33). In the study, the Doa10 ubiquitin ligase preferentially recognized N-

acetylated proteins, which targets the protein for ubiquitylation, resulting in shorter half lives from increased degradation. This likely has relevance for $G$ protein stability, as the $\gamma_{2}$ isoform has been shown to be a substrate for ubiquitylation (34). Proteins with a lysine at position 2, such as $\gamma_{4}$ (Table 2), regardless of $\mathrm{N}$-terminal acetylation status, were found to bind poorly to the Doa10 ubiquitin ligase (33); interestingly, the only other $\gamma$ isoform with a lysine at position 2 is $\gamma_{3}$. Although the $\mathrm{N}$-terminus of $\gamma_{11}$ was not characterized in this study, the proline at position 2 (Table 2) suggests that it is a poor substrate for $\mathrm{N}$-terminal acetyltransferase (26), and thus a poor target for Doa10 ligase; only one other $\gamma$ isoform, $\gamma_{1}$, contains a proline at position 2. Taken together, the lack of or limited acetylation in $\gamma_{1}, \gamma_{3}$, $\gamma_{4}$ and $\gamma_{11}$, in addition to the lysine at position 2 in $\gamma_{3}$ and $\gamma_{4}$, suggest that these isoforms have the capacity for metabolic stability, and may mark a functional divide in the $\gamma$ isoform family. Extrapolating the effects of acetylation on a physiological system, the degree of acetylation of $\beta \gamma$ dimers contained in a receptor:G protein complex may affect the duration of $\beta \gamma$ signaling through regulation of its half life.

A previously published report demonstrated that purified $\beta_{2} \gamma_{2}$ and $\beta_{4} \gamma_{2}$ were more efficient than $\beta_{1} \gamma_{2}$ at coupling $G_{S} \alpha$ to the adenosine $A_{2 A}$ receptor in a reconstitution assay (28). A distinction should be made that the present study measures interactions of receptors with the endogenous pool of $\beta \gamma$ dimers in a cell, allowing for differences in both stoichiometry and subcellular localization to influence formation of an $R: G$ complex. One interpretation of the two studies is that $\beta \gamma$ dimers containing either $\beta_{2}$ or $\beta_{4}$ are able to couple $G_{S} a$ to the $A_{2 A}$ receptor with high efficiency; however, in the context of the HEK-293 cell, both adenosine $A_{1}$ and $A_{2 A}$ receptors have a preference for $\beta \gamma$ dimers containing the $\beta_{4}$ isoform, likely $\beta_{4} \gamma_{5}$. It should also be noted that the adenosine $A_{1}$ receptor has been documented to have a preference for the $G_{i 3}$ a subunit over $G_{i 1} a, G_{i 2} a$ or $G_{O} a$ (35). Although little specificity between $\mathrm{Ga}$ and $\beta \gamma$ has been reported (21), it is possible that $\mathrm{Ga}$ isoforms modulate the specificity of receptor $\beta \gamma$ interactions, and this may be reflected in the differences in affinity observed between $A_{1}: a_{i 1}$ and $A_{2 A}: a_{S}$ fusion proteins for dimers containing $\beta_{4}$. The variability in $\mathrm{Ga}$ isoform may also account for the preference of the adenosine $\mathrm{A}_{2 \mathrm{~A}}$ receptor for $\beta_{2}$ and $\gamma_{7}$ in striatum, where $A_{2 A}$ receptor mediated elevation of cAMP occurs primarily via $G_{\text {olf }} a$ instead of $G_{S} a$ (36). Cell type and differences in transcription may also contribute to the identity of a heterotrimeric $G$ protein that can interact with a receptor. Thus, the increase in $\beta_{4}$ mRNA levels resulting from $A_{2 A}: a_{S}$ fusion protein expression in this study (Fig. 2) may be related to the higher levels of $\beta_{4}$ protein observed with $A_{2 A}: a_{S}$ (Fig. 9). Interestingly, this correlates with another study that reported a decrease in $\beta_{4}$ mRNA levels after ablation of $G_{S}$ a expression using RNAi (9). This suggests that signaling components within a transduction cascade can be regulated in concert beginning at the level of transcription, and thus there are likely many points of control that determine the final makeup of a receptor:G protein complex.

In this analysis, $\beta$ and $\gamma$ isoform are expressed as a percent of the total quantified, which is essentially a zero sum situation where increases in one isoform must be offset by decreases in others. This can be explained by figure 9 , which illustrates a $\sim 15$ percentage point increase in $\gamma_{5}$ associated with $A_{1}: a_{i 1}$ over HEK-293 $\beta \gamma$. The combined percentage point decrease in $\gamma_{2}, \gamma_{7}, \gamma_{10}$ and $\gamma_{12}$ associated with $A_{1}: a_{i 1}$ relative to HEK-293 $\beta \gamma$ agrees very closely with this value (Figs 7 and 9 , and Table 4). In contrast, the increase in $\beta_{4}$ levels associated with $A_{1}: \alpha_{i 1}$ compared to HEK-293 $\beta \gamma$, although significant, is less than two percentage points (Fig. 8). This increase is likely offset by the slight trend lower of $\beta_{2}$ associated with $\mathrm{A}_{1}: \mathrm{a}_{\mathrm{i} 1}$ compared to HEK-293 $\beta \gamma$ (Fig. 8). One interpretation of these differences is that increases in $\gamma_{5}$ levels in $A_{1}: \alpha_{i 1}$ over HEK-293 $\beta \gamma$ can not be explained 
by increases in preference for the $\beta_{4} \gamma_{5}$ dimer alone. Thus, $A_{1}: a_{i 1}$ (and $A_{2 A}: a_{S}$ to a lesser extent) likely also has preferences for $\beta_{1} \gamma_{5}$ and/or $\beta_{2} \gamma_{5}$ dimers.

This specificity for $\gamma_{5}$ may be related to the physiological properties of adenosine receptors. For instance, activation of the adenosine $\mathrm{A}_{2 \mathrm{~A}}$ receptor has been shown to attenuate the inflammatory effects of Helicobactor pylori induced gastritis (37). It has also been shown that $H$. pylori infection up-regulates $\gamma_{5}$ mRNA levels in a human gastric cancer cell line (38); increased transcription of $\gamma_{5}$ may be related to a mechanism by which adenosine receptors interact with specific $G$ protein combinations to signal and counter the effects of inflammation. Indeed, there is mounting evidence that $\beta$ and $\gamma$ levels are dynamic and respond to extracellular cues. For instance, the $\gamma_{3}$ transcript was up-regulated in rat hippocampus following oxidative stress (39), and in activated CD4 + T-cells (40). LPS stimulation of the microglial cell line BV-2 resulted in a transient increase in $\gamma_{12}$ levels (41). Levels of $\beta_{4}$ mRNA and protein increased in human microvascular endothelial cells in response to IL-1 and TNF- $\alpha$ (42), and IFN- $\beta$ was shown to increase $\beta_{4}, \gamma_{2}$ and $\gamma_{11}$ transcripts in Ubp43 ${ }^{-/-}$bone marrow derived macrophages (43). These examples suggest that extracellular stimuli may prime a cell to express a particular profile of $\beta$ and $\gamma$ isoforms; it is of critical importance to determine if specific receptors within the cellular context have inherent preferences for the resulting $\beta \gamma$ dimers.

As an example of how dynamic regulation of $\beta$ and $\gamma$ transcription may influence signaling, the IFN- $\beta$ mediated increase in $\beta_{4}$ mentioned above may be examined in the context of adenosine receptor signaling. Increased $\beta_{4}$ expression could facilitate the population of adenosine $A_{2 A}$ receptor complexes containing $\beta_{4} \gamma$ dimers, which compared to $A_{2 A}$ receptor complexes containing $\beta_{1} \gamma$ dimers, have the ability to shift the equilibrium of the $A_{2 A}$ receptor population toward more high affinity agonist binding sites (44). This would have the effect of lowering the concentration of adenosine required for activation of the $\mathrm{A}_{2 \mathrm{~A}}$ receptor. Interestingly, a similar mechanism for increased adenosine receptor signaling was proposed after the discovery that IFN- $\beta$ induced the expression of CD73, an ecto-5' nucleotidase that increases adenosine production (45); the authors proposed that increased adenosine receptor signaling may be one way that IFN- $\beta$ ameliorates the progression of multiple sclerosis.

The question of how $\beta$ and $\gamma$ subunit diversity translates into signaling specificity has been enigmatic. It is possible that multiple mechanisms exist for heterogeneity of $\beta$ and $\gamma$ isoforms to influence cellular signaling. Regardless, this innovative approach will allow the question to be fully addressed through the quantitative measurement of changes in both $\beta$ and $\gamma$ isoforms with high precision under a variety of experimental conditions.

\section{Acknowledgments}

We would like to thank Dr. James Garrison for support during the course of these studies, and helpful discussions during the preparation of this manuscript. Thanks go to Dr. Joel Linden for the generous gift of the pDoubleTrouble vectors containing adenosine $\mathrm{A}_{1}$ and $\mathrm{A}_{2} \mathrm{~A}$ receptors. We also thank Dr. Thurl Harris, Jessica Ng and Jiping Zhou for expert technical assistance. We acknowledge the University of Virginia Pratt Committee for its generous support of the Biomedical Research Facility.

\section{References}

1. Gilman AG. Nobel Lecture. G proteins and regulation of adenylyl cyclase. Biosci. Rep. 1995; 15:65-97. [PubMed: 7579036]

2. Birnbaumer L. Expansion of signal transduction by $G$ proteins. The second 15 years or so: from 3 to 16 alpha subunits plus betagamma dimers. Biochim. Biophys. Acta. 2007; 1768:772-793. [PubMed: 17258171] 
3. Hildebrandt JD. Role of subunit diversity in signaling by heterotrimeric $\mathrm{G}$ proteins. Biochem. Pharmacol. 1997; 54:325-339. [PubMed: 9278091]

4. Downes GB, Gautam N. The G protein subunit gene families. Genomics. 1999; 62:544-552. [PubMed: 10644457]

5. McIntire WE. Structural determinants involved in the formation and activation of $\mathrm{G}$ protein betagamma dimers. Neurosignals. 2009; 17:82-99. [PubMed: 19212142]

6. Schwindinger WF, Betz KS, Giger KE, Sabol A, Bronson SK, Robishaw JD. Loss of G protein gamma 7 alters behavior and reduces striatal alpha(olf) level and cAMP production. J. Biol. Chem. 2003; 278:6575-6579. [PubMed: 12488442]

7. Schwindinger WF, Giger KE, Betz KS, Stauffer AM, Sunderlin EM, Sim-Selley LJ, Selley DE, Bronson SK, Robishaw JD. Mice with deficiency of G protein gamma3 are lean and have seizures. Mol. Cell Biol. 2004; 24:7758-7768. [PubMed: 15314181]

8. Hwang JI, Fraser ID, Choi S, Qin XF, Simon MI. Analysis of C5a-mediated chemotaxis by lentiviral delivery of small interfering RNA. Proc. Natl. Acad. Sci. U. S. A. 2004; 101:488-493. [PubMed: 14699051]

9. Krumins AM, Gilman AG. Targeted knockdown of G protein subunits selectively prevents receptormediated modulation of effectors and reveals complex changes in non-targeted signaling proteins. J. Biol. Chem. 2006; 281:10250-10262. [PubMed: 16446365]

10. Mann M. Functional and quantitative proteomics using SILAC. Nat. Rev. Mol. Cell Biol. 2006; 7:952-958. [PubMed: 17139335]

11. McIntire WE, MacCleery G, Murphree LJ, Kerchner KR, Linden J, Garrison JC. Influence of differential stability of $\mathrm{G}$ protein betagamma dimers containing the gamma11 subunit on functional activity at the M1 muscarinic receptor, A1 adenosine receptor, and phospholipase Cbeta. Biochemistry. 2006; 45:11616-11631. [PubMed: 16981721]

12. Mayeenuddin LH, McIntire WE, Garrison JC. Differential sensitivity of P-Rex1 to isoforms of G protein betagamma dimers. J. Biol. Chem. 2006; 281:1913-1920. [PubMed: 16301321]

13. Livak KJ, Schmittgen TD. Analysis of relative gene expression data using real-time quantitative PCR and the 2(-Delta Delta C(T)) Method. Methods. 2001; 25:402-408. [PubMed: 11846609]

14. Robeva AS, Woodard R, Luthin DR, Taylor HE, Linden J. Double tagging recombinant A1- and A2A-adenosine receptors with hexahistidine and the FLAG epitope. Development of an efficient generic protein purification procedure. Biochem. Pharmacol. 1996; 51:545-555. [PubMed: 8619901]

15. Graber SG, Figler RA, Garrison JC. Expression and purification of functional G protein alpha subunits using a baculovirus expression system. J. Biol. Chem. 1992; 267:1271-1278. [PubMed: 1730649]

16. Cadene M, Chait BT. A robust, detergent-friendly method for mass spectrometric analysis of integral membrane proteins. Anal. Chem. 2000; 72:5655-5658. [PubMed: 11101244]

17. Fletcher JE, Lindorfer MA, DeFilippo JM, Yasuda H, Guilmard M, Garrison JC. The G protein beta5 subunit interacts selectively with the Gq alpha subunit. J. Biol. Chem. 1998; 273:636-644. [PubMed: 9417126]

18. Graber SG, Figler RA, Garrison JC. Expression and purification of G-protein alpha subunits using baculovirus expression system. Methods Enzymol. 1994; 237:212-226. [PubMed: 7934998]

19. Graber SG, Lindorfer MA, Garrison JC. Expression and purification of G protein beta gamma subunuts using a baculovirus expression system. Methods Neurosci. 1996; 29:207-226.

20. Lindorfer MA, Myung CS, Savino Y, Yasuda H, Khazan R, Garrison JC. Differential activity of the $\mathrm{G}$ protein beta5 gamma2 subunit at receptors and effectors. J. Biol. Chem. 1998; 273:3442934436. [PubMed: 9852110]

21. Ueda H, Morishita R, Katoh-Semba R, Kato K, Asano T. G protein gamma subunits coimmunoprecipitated with antibodies against alpha subunits: identification of major isoforms in cultured cells by silver stain and immunoblotting with conventional transfer procedure. J. Biochem. 1998; 124:1033-1037. [PubMed: 9792930]

22. Kilpatrick EL, Hildebrandt JD. Sequence dependence and differential expression of Ggamma5 subunit isoforms of the heterotrimeric $\mathrm{G}$ proteins variably processed after prenylation in mammalian cells. J. Biol. Chem. 2007; 282:14038-14047. [PubMed: 17353195] 
23. Wise A, Sheehan M, Rees S, Lee M, Milligan G. Comparative analysis of the efficacy of A1 adenosine receptor activation of $\mathrm{Gi} / \mathrm{o}$ alpha $\mathrm{G}$ proteins following coexpression of receptor and $\mathrm{G}$ protein and expression of A1 adenosine receptor-Gi/o alpha fusion proteins. Biochemistry. 1999; 38:2272-2278. [PubMed: 10029519]

24. Cook LA, Schey KL, Wilcox MD, Dingus J, Ettling R, Nelson T, Knapp DR, Hildebrandt JD. Proteomic analysis of bovine brain $\mathrm{G}$ protein gamma subunit processing heterogeneity. Mol. Cell Proteomics. 2006; 5:671-685. [PubMed: 16332732]

25. Frottin F, Martinez A, Peynot P, Mitra S, Holz RC, Giglione C, Meinnel T. The proteomics of Nterminal methionine cleavage. Mol. Cell Proteomics. 2006; 5:2336-2349. [PubMed: 16963780]

26. Arnesen T, Van Damme P, Polevoda B, Helsens K, Evjenth R, Colaert N, Varhaug JE, Vandekerckhove J, Lillehaug JR, Sherman F, Gevaert K. Proteomics analyses reveal the evolutionary conservation and divergence of N-terminal acetyltransferases from yeast and humans. Proc. Natl. Acad. Sci. U. S. A. 2009; 106:8157-8162. [PubMed: 19420222]

27. Morishita R, Ueda H, Kato K, Asano T. Identification of two forms of the gamma subunit of G protein, gamma10 and gamma11, in bovine lung and their tissue distribution in the rat. FEBS Lett. 1998; 428:85-88. [PubMed: 9645481]

28. McIntire WE, MacCleery G, Garrison JC. The G protein beta subunit is a determinant in the coupling of Gs to the beta 1-adrenergic and A2a adenosine receptors. J. Biol. Chem. 2001; 276:15801-15809. [PubMed: 11278863]

29. De Lean A, Stadel JM, Lefkowitz RJ. A ternary complex model explains the agonist-specific binding properties of the adenylate cyclase-coupled beta-adrenergic receptor. J. Biol. Chem. 1980; 255:7108-7117. [PubMed: 6248546]

30. Lambright DG, Sondek J, Bohm A, Skiba NP, Hamm HE, Sigler PB. The 2.0 A crystal structure of a heterotrimeric G protein [see comments]. Nature. 1996; 379:311-319. [PubMed: 8552184]

31. Venter JC, et al. The sequence of the human genome. Science. 2001; 291:1304-1351. [PubMed: 11181995]

32. Gao Z, Robeva AS, Linden J. Purification of A1 adenosine receptor-G-protein complexes: effects of receptor down-regulation and phosphorylation on coupling. Biochem. J. 1999; 338(Pt 3):729736. [PubMed: 10051446]

33. Hwang CS, Shemorry A, Varshavsky A. N-terminal acetylation of cellular proteins creates specific degradation signals. Science. 2010; 327:973-977. [PubMed: 20110468]

34. Hamilton MH, Cook LA, McRackan TR, Schey KL, Hildebrandt JD. Gamma 2 subunit of G protein heterotrimer is an N-end rule ubiquitylation substrate. Proc. Natl. Acad. Sci. U. S. A. 2003; 100:5081-5086. [PubMed: 12700354]

35. Freissmuth M, Schutz W, Linder ME. Interactions of the bovine brain A1-adenosine receptor with recombinant $\mathrm{G}$ protein alpha-subunits. Selectivity for rGi alpha-3. J. Biol. Chem. 1991; 266:17778-17783. [PubMed: 1917922]

36. Schwindinger WF, Mihalcik LJ, Giger KE, Betz KS, Stauffer AM, Linden J, Herve D, Robishaw JD. Adenosine A2A receptor signaling and golf assembly show a specific requirement for the gamma7 subtype in the striatum. J. Biol. Chem. 2010; 285:29787-29796. [PubMed: 20639202]

37. Alam MS, Kurtz CC, Wilson JM, Burnette BR, Wiznerowicz EB, Ross WG, Rieger JM, Figler RA, Linden J, Crowe SE, Ernst PB. A2A adenosine receptor (AR) activation inhibits proinflammatory cytokine production by human CD4+ helper T cells and regulates Helicobacterinduced gastritis and bacterial persistence. Mucosal. Immunol. 2009; 2:232-242. [PubMed: 19262506]

38. Hirata Y, Maeda S, Ohmae T, Shibata W, Yanai A, Ogura K, Yoshida H, Kawabe T, Omata M. Helicobacter pylori induces IkappaB kinase alpha nuclear translocation and chemokine production in gastric epithelial cells. Infect. Immun. 2006; 74:1452-1461. [PubMed: 16495515]

39. Wang X, Pal R, Chen XW, Kumar KN, Kim OJ, Michaelis EK. Genome-wide transcriptome profiling of region-specific vulnerability to oxidative stress in the hippocampus. Genomics. 2007; 90:201-212. [PubMed: 17553663]

40. Dubeykovskiy A, McWhinney C, Robishaw JD. Runx-dependent regulation of G-protein gamma3 expression in T-cells. Cell Immunol. 2006; 240:86-95. [PubMed: 16904090] 
41. Larson KC, Lipko M, Dabrowski M, Draper MP. Gng12 is a novel negative regulator of LPSinduced inflammation in the microglial cell line BV-2. Inflamm. Res. 2010; 59:15-22. [PubMed: 19568691]

42. Nguyen DK, Montesinos MC, Williams AJ, Kelly M, Cronstein BN. Th1 cytokines regulate adenosine receptors and their downstream signaling elements in human microvascular endothelial cells. J. Immunol. 2003; 171:3991-3998. [PubMed: 14530318]

43. Zou W, Kim JH, Handidu A, Li X, Kim KI, Yan M, Li J, Zhang DE. Microarray analysis reveals that Type I interferon strongly increases the expression of immune-response related genes in Ubp43 (Usp18) deficient macrophages. Biochem. Biophys. Res. Commun. 2007; 356:193-199. [PubMed: 17349616]

44. Murphree LJ, Marshall MA, Rieger JM, MacDonald TL, Linden J. Human A(2A) adenosine receptors: high-affinity agonist binding to receptor-G protein complexes containing Gbeta(4). Mol. Pharmacol. 2002; 61:455-462. [PubMed: 11809871]

45. Niemela J, Ifergan I, Yegutkin GG, Jalkanen S, Prat A, Airas L. IFN-beta regulates CD73 and adenosine expression at the blood-brain barrier. Eur. J. Immunol. 2008; 38:2718-2726. [PubMed: 18825744] 
A

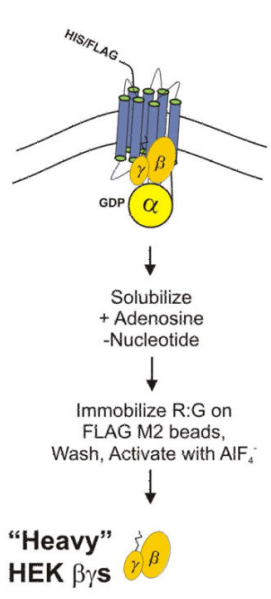

B
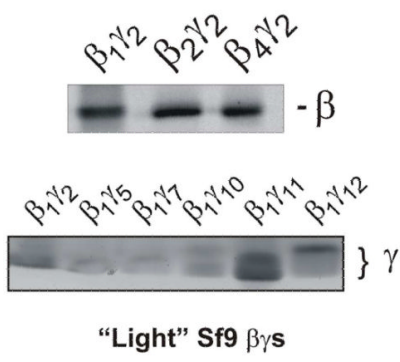

Tryptic Digestion,
C

"Heavy" HEK $\beta \gamma$ s

"Light" Sf9 $\beta \gamma \mathrm{s}$

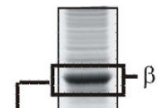
LC/MS/MS

$\gamma$

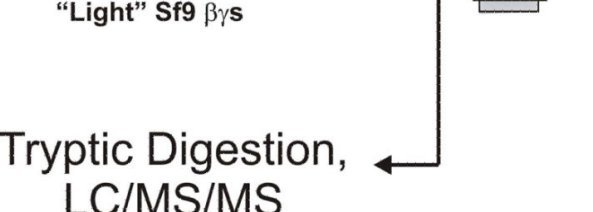

Fig. 1.

A) Flow chart illustrating expression of epitope tagged receptor fusion protein in HEK-293 cells cultured in heavy SILAC media, purification of R:G complex, and recovery of native heavy $\beta \gamma$ dimers associated with the receptor fusion protein; B) Example of purified recombinant $\beta \gamma$ dimers from Sf9 cells cultured in light media used for the quantitation of $\beta$ and $\gamma$ isoform levels. $250 \mathrm{ng}$ each of $\beta_{1} \gamma_{2}, \beta_{2} \gamma_{2}$ and $\beta_{4} \gamma_{2}$ were stained with Coomassie blue (above), and $50 \mathrm{ng}$ each of $\beta_{1} \gamma_{2}, \beta_{1} \gamma_{5}, \beta_{1} \gamma_{7}, \beta_{1} \gamma_{10}, \beta_{1} \gamma_{11}$ and $\beta_{1} \gamma_{12}$ were stained with silver (below); C) Native $\beta \gamma$ in $A$ combined with Sf9 standard $\beta \gamma$ in $B$ and separated by SDS-PAGE, in preparation for mass spectrometric analysis (see arrow). 


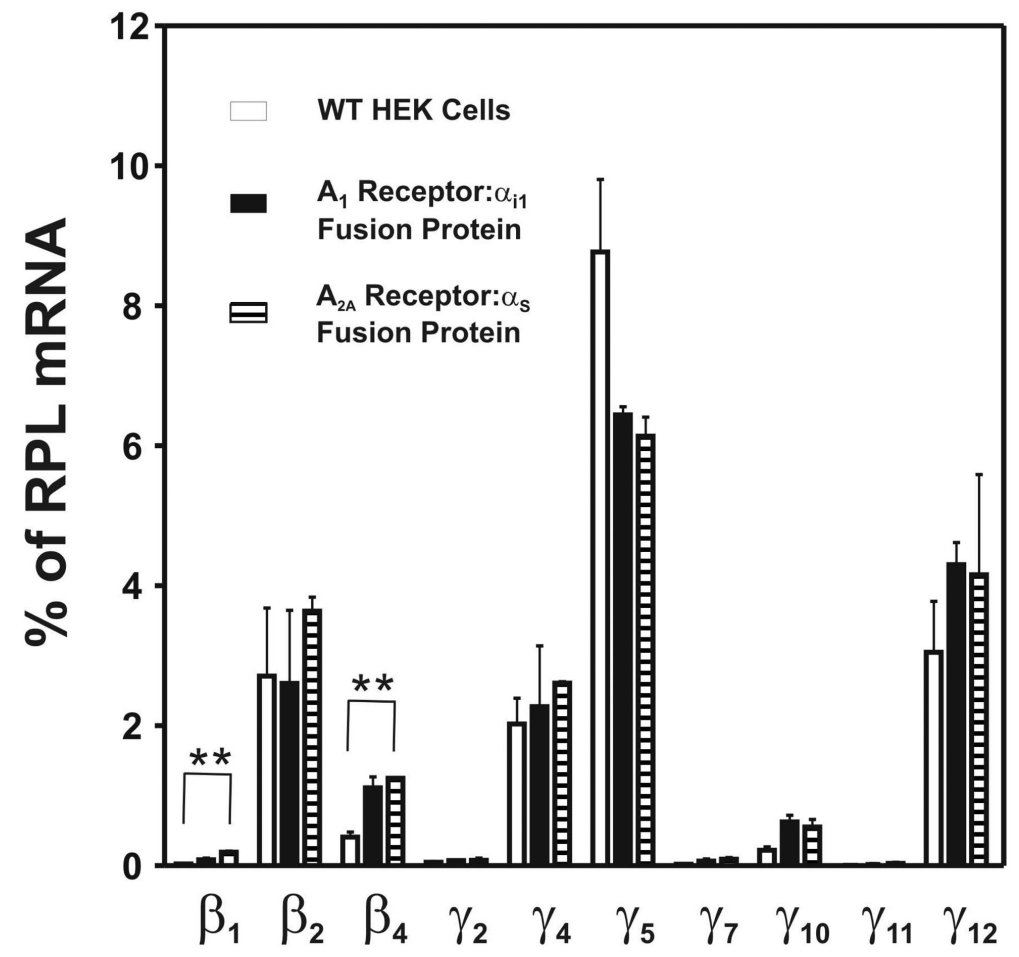

Fig. 2.

Real Time QPCR Analysis of $\beta$ and $\gamma$ mRNA Transcript Levels in HEK-293 Cells- Isoform specific human primers (see Table 1) were used to measure the mRNA levels of various $\beta$ and $\gamma$ isoforms, expressed as a percent of the housekeeping gene ribosomal protein 13A (RPL) in wild type HEK-293 cells (white bars), HEK cells expressing

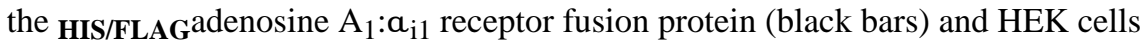
expressing the HIS/FLAG adenosine $\mathrm{A}_{2 \mathrm{~A}}: \mathrm{a}_{\mathrm{S}}$ receptor fusion protein (hatched bars). $\beta_{1}$ mRNA was eight-fold higher in $\mathrm{A}_{2 \mathrm{~A}}: a_{S}$ cells over wild type HEK cells $(0.20 \%$ vs $0.03 \%$ of RPL); $\beta_{4}$ mRNA was $\sim$ three-fold higher in $A_{2 A}: a_{S}$ cells over wild type HEK cells $(1.25 \%$ vs $0.4 \%$ of RPL). $* *=\mathrm{p}<0.01$. 

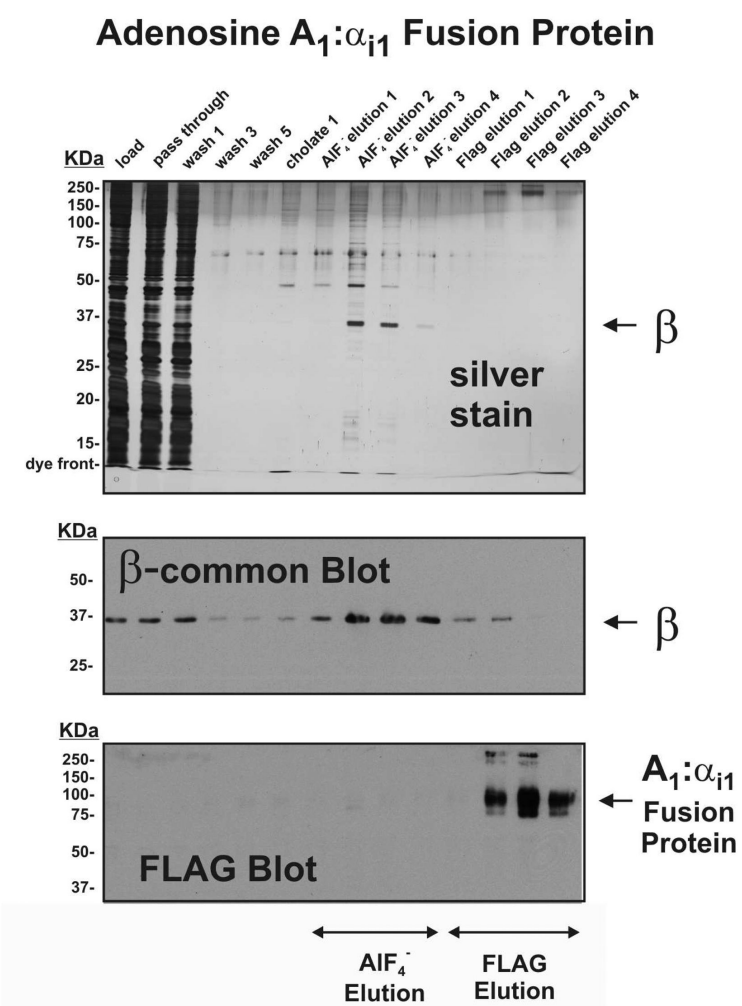

Fig. 3.

Purification of Native $\beta \gamma$ Dimers Using the HIS/FLAGA denosine $A_{1}: a_{i 1}$ Receptor Fusion Protein Expressed in HEK-293 Cells. Native $\beta \gamma$ dimers associated with the receptor fusion protein were released after incubation with $\mathrm{AlF}_{4}^{-}$; subsequently, FLAG peptide was used to elute the remaining adenosine $A_{1}: a_{i 1}$ receptor fusion protein. Fractions from the purification were separated using SDS-PAGE and either stained with silver (above) or transferred to nitrocellulose and blotted with $\beta$-common (middle) and FLAG (below) antibodies. The silver stained gel illustrates the purity of the $\beta \gamma$ released from the fusion protein, and the $\beta$ common western blot confirms the identity of the protein band at $36 \mathrm{kDa}$. The FLAG western blot illustrates elution of adenosine $A_{1}: a_{i 1}$ fusion protein, with a predicted molecular weight of approximately $80 \mathrm{kDa}$. 


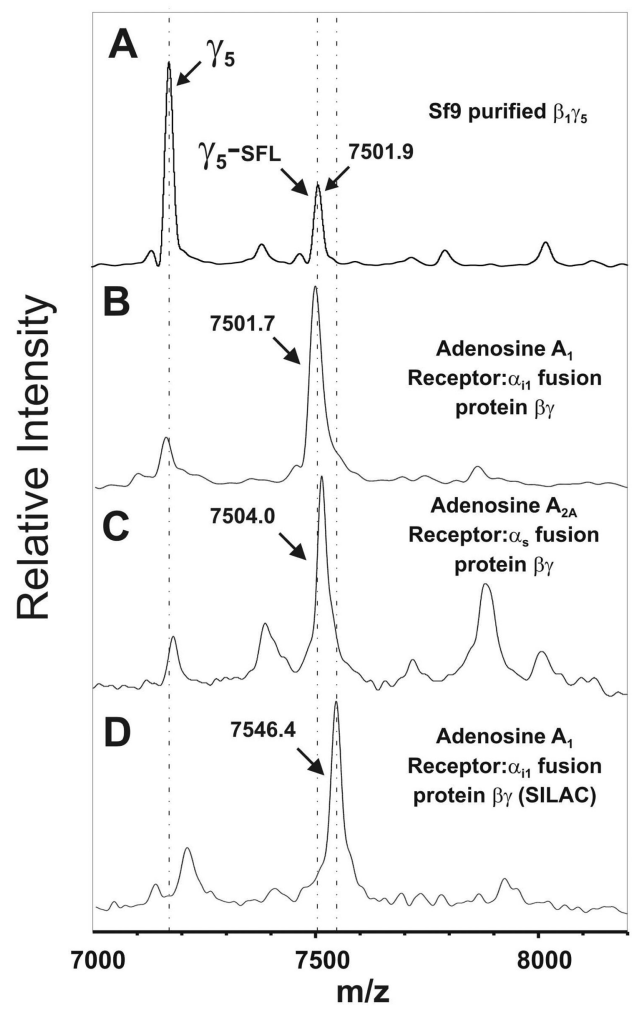

Fig. 4.

MALDI Mass Spectrometric Analysis of Intact $\gamma$ Isoforms- $A$ ) Light $\beta_{1} \gamma_{5}$ purified from Sf9 cells grown in standard media; $B$ ) Purified light $\beta \gamma$ released from $A_{1}: a_{i 1}$ fusion protein expressed in HEK-293 cells cultured in standard media; $C$ ) Purified light $\beta \gamma$ released from $\mathrm{A}_{2 \mathrm{~A}}: a_{\mathrm{S}}$ fusion protein expressed in HEK-293 cells cultured in standard media; $D$ ) Purified heavy $\beta \gamma$ released from $A_{1}: a_{i 1}$ fusion protein expressed in HEK-293 cells cultured in media containing $\left[{ }^{13} \mathrm{C}_{6}\right]$ Arg and $\left[{ }^{13} \mathrm{C}_{6}\right]$ Lys. Dashed lines align with peaks coinciding with expected average masses for conventionally processed $\gamma_{5}$ (geranylgeranylation, methylation at C65 and loss of C-terminal SFL sequence mass), and $\gamma_{5}$-SFL (geranylgeranylation at C65 and retention of C-terminal SFL sequence) in spectra $A, B$ and $C$. Dashed line bisecting peak in spectrum $D$ indicates expected mass of $\gamma_{5}$-SFL containing $\left[{ }^{13} \mathrm{C}_{6}\right]$ Arg and $\left[{ }^{13} \mathrm{C}_{6}\right]$ Lys. 

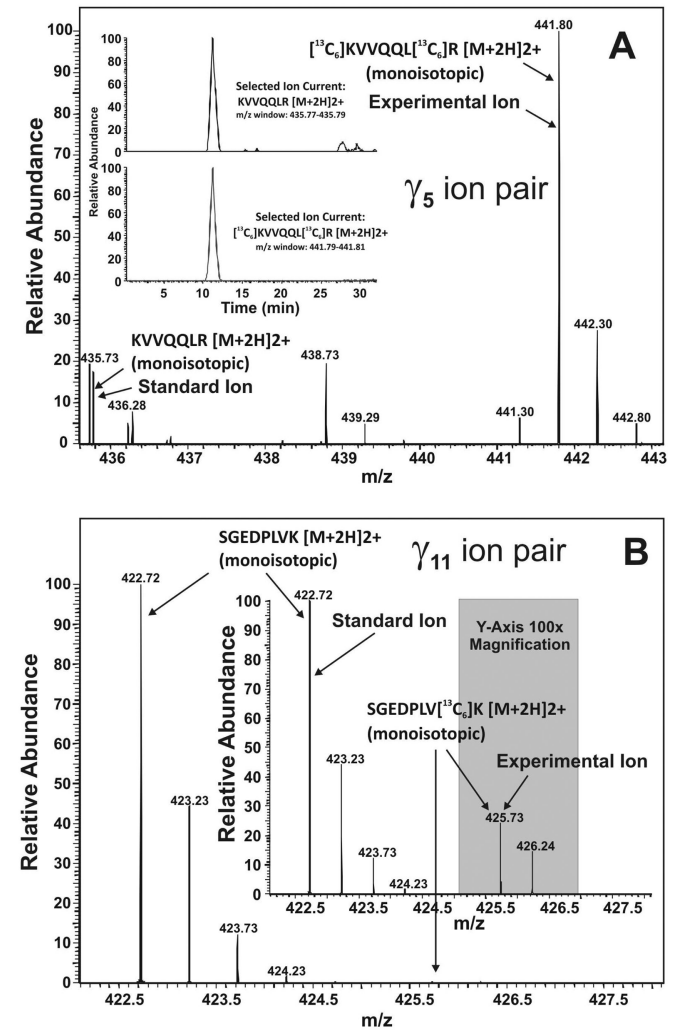

Fig. 5.

Example comparison of Heavy and Light Ion Pairs used to Determine H:L Ratio for $\gamma_{5}$ and $\gamma_{11^{-}} A$ ) Light (from Sf9 $\beta_{1} \gamma_{5}$ ) and heavy (from $\mathrm{A}_{1}: \mathrm{a}_{\mathrm{i} 1}$ fusion protein $\beta \gamma$ ) $[\mathrm{M}+2 \mathrm{H}] 2+$ ions from the KVVQQLR peptide derived from the $\gamma_{5}$ isoform. Inset illustrates the selected ion currents from the light and heavy ions plotted against retention time by HPLC; H:L ratios were determined from these peaks as described in Materials and Methods under Determination of Ratios of Heavy and Light Peptides. B) Light and heavy $[\mathrm{M}+2 \mathrm{H}] 2+$ ions from the SGEDPLVK peptide derived from the $\gamma_{11}$ isoform. Note that the heavy ion is not visible in the main spectrum; however, upon 100x enlargement of the Y-axis (inset spectrum), the heavy ion becomes evident. 

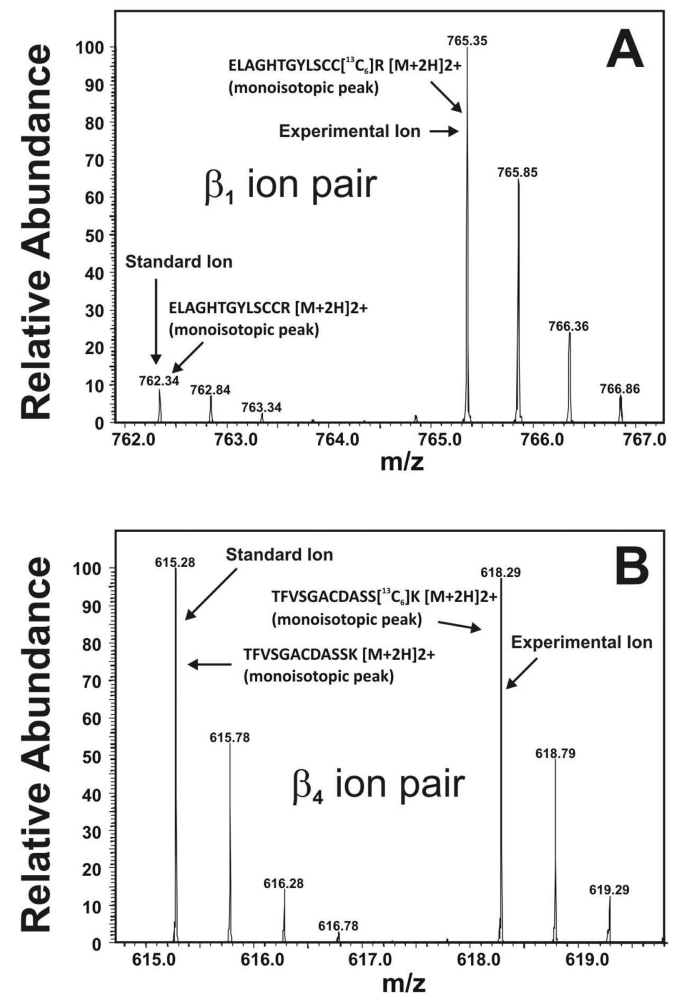

Fig. 6.

Comparison of Heavy and Light Ion Pairs used to Determine H:L Ratio for $\beta_{1}$ and $\beta_{4}-A$ ) Light and heavy $[\mathrm{M}+2 \mathrm{H}] 2+$ ions from the ELAGHTGYLSCCR peptide derived from the $\beta_{1}$ isoform. $B$ ) Light and heavy $[\mathrm{M}+2 \mathrm{H}] 2+$ ions from the TFVSGACDASSK peptide derived from the $\beta_{4}$ isoform. 

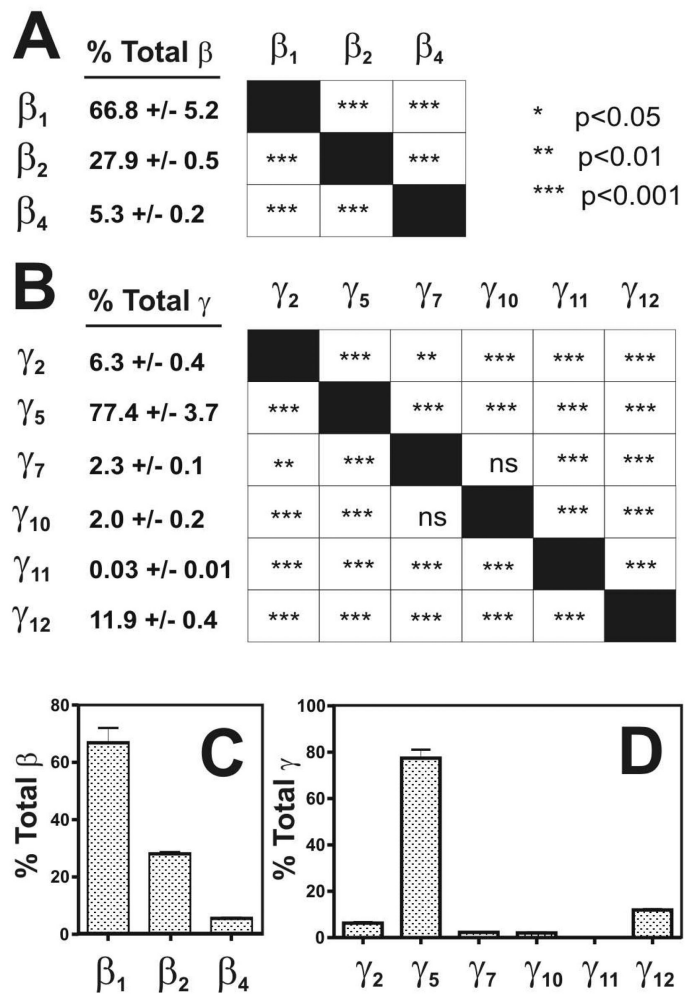

Fig. 7.

Quantitation of $\beta$ and $\gamma$ Isoforms Associated with the $\mathrm{A}_{1}: \mathrm{a}_{\mathrm{i} 1}$ Fusion Protein- $A$ ) Matrix of $\beta$ isoforms; each isoform is expressed as a percentage of the sum of all $\beta$ protein in each sample. Asterisks illustrate significant differences in comparison of $\beta$ isoform levels. $B$ ) Matrix of $\gamma$ isoforms; each isoform is expressed as a percentage of the sum of $\gamma$ protein in each sample. Asterisks illustrate significant differences in comparisons between $\gamma$ isoform levels; ns, not significant. $C$ ) Bar graph representation of the data expressed in $A$. $D$ ) Bar graph representation of the data expressed in $B$. (See Table 3 for list of $\beta$ and $\gamma$ peptides used to determine $\mathrm{H}: \mathrm{L}$ ratios and $n$ numbers). 

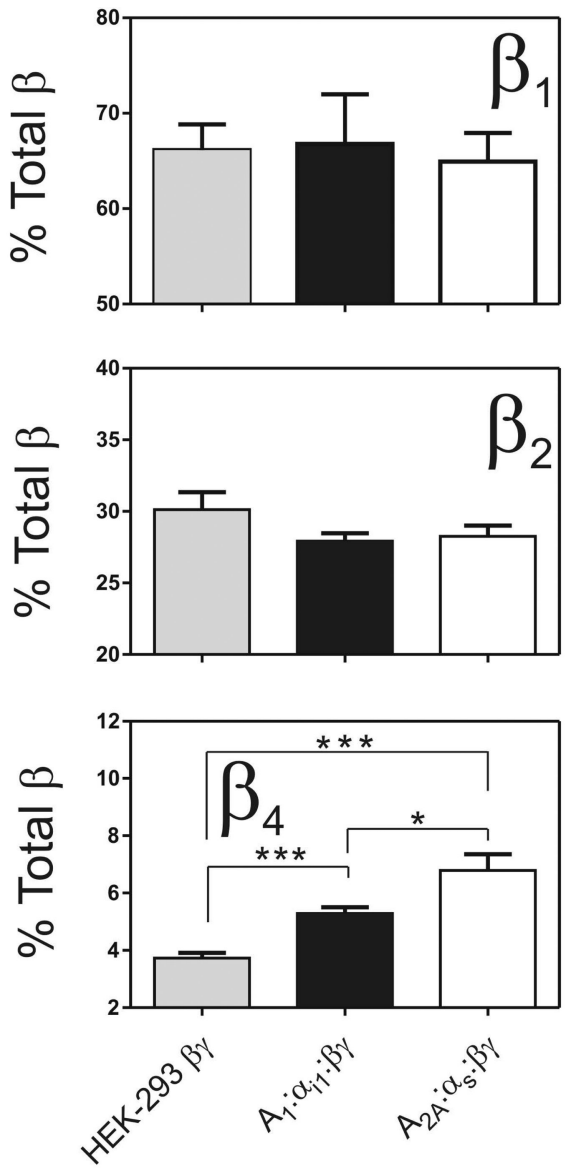

Fig. 8.

Comparison of $\beta$ Isoforms Associated with $A_{1}: a_{i 1}, A_{2 A}: a_{S}$ and Enriched HEK-293 $\beta \gamma-H: L$ ratios derived from $\beta$ tryptic peptides were used to calculate the concentration of the $\beta_{1}, \beta_{2}$ and $\beta_{4}$ isoforms purified from the two fusion proteins, or present in the enriched HEK-293 $\beta \gamma$ fraction. (See Table 3 for list of $\beta$ peptides used to determine H:L ratios and $n$ numbers). The concentration of each $\beta$ isoform was converted to moles, and the moles of each $\beta$ isoform was divided by the sum total moles of all the $\beta$ isoforms in the sample. Each $\beta$ isoform is expressed as a percent of the total moles quantified, $+/-$ SEM. $(*=\mathrm{p}<0.05$; $* * *=$ $\mathrm{p}<0.001)$. Numerical values for the data are presented in figure $7 \mathrm{~A}$ and table 4. 

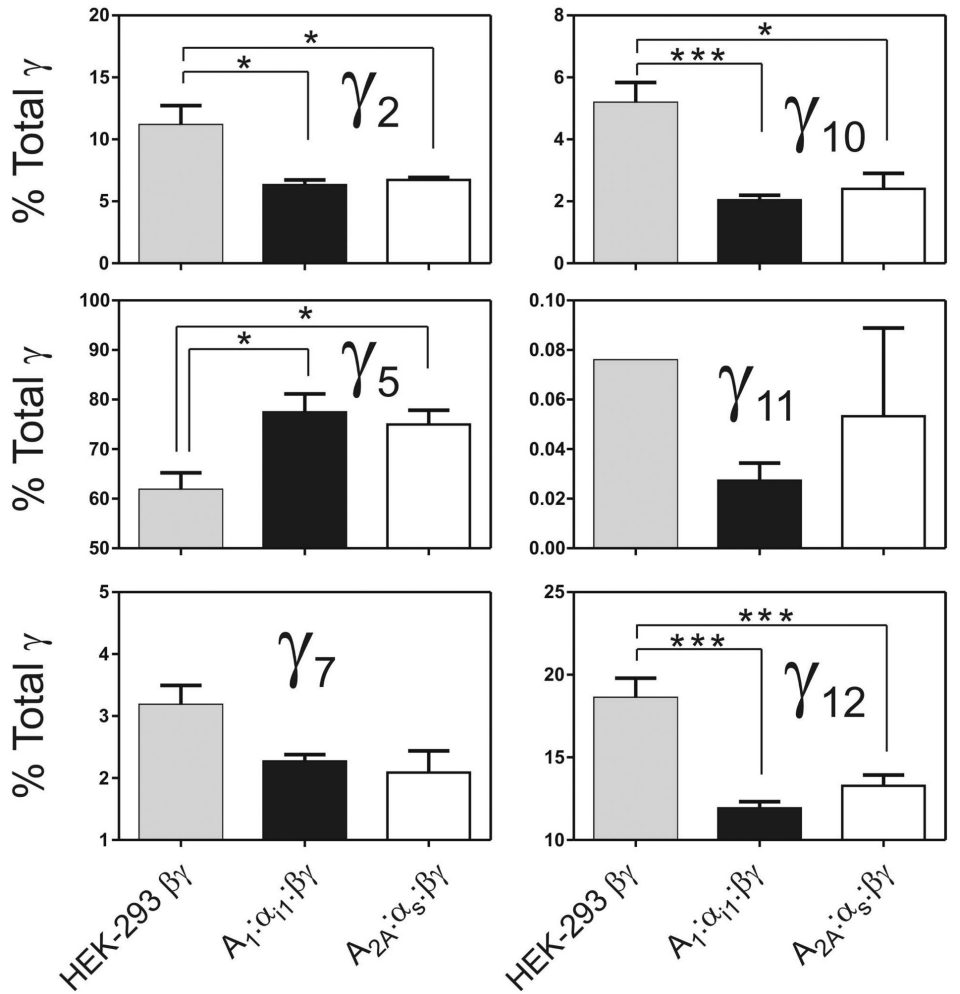

Fig. 9.

Comparison of $\gamma$ Isoforms Associated with $A_{1}: a_{i 1}, A_{2 A}: a_{S}$ and Enriched HEK-293 $\beta \gamma-H: L$ ratios derived from $\gamma$ tryptic peptides were used to calculate the concentration of the $\gamma_{2}, \gamma_{5}$, $\gamma_{7}, \gamma_{10}, \gamma_{11}$ and $\gamma_{12}$ isoforms purified from the two fusion proteins, or present in the enriched HEK-293 $\beta \gamma$ fraction. (See Table 3 for list of $\gamma$ peptides used to determine H:L ratios and $n$ numbers). The concentration of each $\gamma$ isoform was converted to moles, and the moles of each $\gamma$ isoform was divided by the sum total moles of all the $\gamma$ isoforms in the sample. Each $\gamma$ isoform is expressed as a percent of the total moles quantified, $+/-$ SEM. (* $=\mathrm{p}<0.05 ; * * *=\mathrm{p}<0.001)$. Numerical values for the data are presented in figure $7 \mathrm{~B}$ and table 4. 
Table 1

Human PCR primers used for the quantitation of $\beta$ and $\gamma$ mRNA transcripts in HEK-293 cells.

\begin{tabular}{ccc}
\hline $\begin{array}{c}\text { Target } \\
\text { Gene }\end{array}$ & $\begin{array}{c}\text { Sense } \\
\text { Primer }\end{array}$ & $\begin{array}{c}\text { Antisense } \\
\text { Primer }\end{array}$ \\
\hline$\beta_{1}$ & GACTGCTGTTGGATTCTG & CACTACTGCTGCTATGAAG \\
$\beta_{2}$ & CGCCTGTGATGCCTCTATC & GCCGTTGGGGAAGAAAGC \\
$\beta_{3}$ & ACCTGTCCATCCTTCTCTG & CCTCAAACTGTGCTCCTC \\
$\beta_{4}$ & AATGTGAGAGTAAGCCGAGAGTTG & TCCAGAATGCCCAGTGAATGTG \\
$\beta_{5}$ & GCTCTCCGCTTCCCTCTC & CTTGGCTCGCTCCTCCTC \\
$\gamma_{1}$ & CCAAATGTTGTGAAGAAG & GCTTAGTAGTAATAGTATGC \\
$\gamma_{2}$ & TTTCTTTCTTCCTTCTCCTCTACCC & ACCAGTCCAGCCTTATCTCCAC \\
$\gamma_{3}$ & CATCCCATCCCTAACCCTTG & CCATCCCTCTCCATTGTCTG \\
$\gamma_{4}$ & GGGCAGTAGAATGAAAGAGG & CACACGGAGTTAGAGAATGG \\
$\gamma_{5}$ & ATCCAGTGATATTCAAGAGAGC & GACGAAAGTAGAAGTTTGTATATTATG \\
$\gamma_{7}$ & GCAGGAATGGCAGGAAGG & AGATGGCTCGTTGGAAAGG \\
$\gamma_{8}$ & CGCAAGACGGTGGAACAG & CTCGCAGAAAGCCAGGAG \\
$\gamma_{9}\left(\gamma_{8 \text { cone }}\right)$ & AGGTGGCTGTCTGATAAG & CTGTGATGAAGAGAAGGTG \\
$\gamma_{10}$ & ACACTCAAGGTCTCTCAG & AAGGCAGTCATTCATCAC \\
$\gamma_{11}$ & TCTCAAACTTAACCCTCATC & GTCCCGAAACAACTGAAG \\
$\gamma_{12}$ & TCCTCGCCTCTTCCCAACAAC & AAACAGTAACCCAACATAAAGCCATAG \\
$\gamma_{13}$ & GACCTGATGAAGAACAAC & TACAAGATGGAGTGAGTG
\end{tabular}


Table 2

Determination of N-terminal structure of $\gamma$ isoforms by ESI-MS/MS mass spectrometry.

\begin{tabular}{|c|c|c|c|}
\hline \multirow[b]{2}{*}{ Isoform } & \multirow[b]{2}{*}{$\begin{array}{l}\text { N-Terminal } \\
\text { Sequence }\end{array}$} & \multicolumn{2}{|c|}{$\begin{array}{c}\text { Structure of G } \gamma \\
\text { N-Terminal Residue } \\
\end{array}$} \\
\hline & & $\begin{array}{l}\beta \gamma \text { from } \\
A_{1} R: G\end{array}$ & $\begin{array}{l}\beta \gamma \text { from } \\
A_{2 A} \text { R:G }\end{array}$ \\
\hline$\gamma_{2}$ & *MASNN & Ac-A & Ac-A \\
\hline$\gamma_{4}$ & MKEGM & ${ }^{\#_{\mathrm{M}}}$ & ${ }^{\#_{\mathrm{M}}}$ \\
\hline$\gamma_{5}$ & *MSGSS & Ac-S & Ac-S \\
\hline$\gamma_{7}$ & *MSATN & Ac-S & Ac-S \\
\hline$\gamma_{10}$ & *MSSGA & Ac-S & Ac-S \\
\hline$\gamma_{11}$ & MPALH & n.d. & n.d. \\
\hline$\gamma_{12}$ & MSSKT & n.d. & n.d. \\
\hline \multicolumn{4}{|c|}{ * cleavage of $\mathrm{N}$-terminal methionine observed } \\
\hline
\end{tabular}

Ac=acetylation; n.d., not determined 


\section{Table 3}

Peptides from $\beta$ and $\gamma$ Isoforms used for H:L Ion Pair Analysis. N values indicate the number of H:L ratios used from each comparison in the analysis of $\beta$ and $\gamma$ isoform levels. N.D. $=$ not determined; a protein standard for $\gamma_{4}$ was not used in this study.

\begin{tabular}{|c|c|c|c|c|}
\hline \multirow[t]{2}{*}{ Isoform } & \multirow[t]{2}{*}{ M.W. } & \multirow[t]{2}{*}{$\begin{array}{l}A_{1}: a_{i 1} \text { vs Sf9 } \beta \gamma \\
\text { (Two experiments) }\end{array}$} & \multirow[t]{2}{*}{$\begin{array}{l}A_{1}: a_{i 1} \text { vs } A_{2 A}: a_{S} \\
\text { (Two experiments) }\end{array}$} & \multirow[t]{2}{*}{$\begin{array}{l}A_{1}: a_{i 1} \text { vs Enriched } \\
\text { HEK-293 } \beta \gamma \text { Fraction } \\
\text { (One experiment) }\end{array}$} \\
\hline & & & & \\
\hline$\beta_{2}$ & 37344 & $\begin{array}{l}\text { ACGDSTLTQITAGLDPVGR } \\
\text { LIIWDSYTTNK } \\
\text { TFVSGACDASIK } \\
\text { IYAMHWGTDSR } \\
\text { LLVSASQDGK }\end{array}$ & $\begin{array}{l}\text { ACGDSTLTQITAGLDPVGR } \\
\text { LIIWDSYTTNK } \\
\text { TFVSGACDASIK }\end{array}$ & $\begin{array}{l}\text { ACGDSTLTQITAGLDPVGR } \\
\text { LLLAGYDDFNCNIWDAMK } \\
\text { TFVSGACDASIK } \\
\text { ADQELLMYSHDNIICGITSVAFSR } \\
\text { FLDDNQIITSSGDTTCALWDIETGQQTVGFAGHSGDVMSLSLAPDGR } \\
\text { KACGDSTLTQITAGLDPVGR } \\
\text { QTFIGHESDINAVAFFPNGYAFTTGSDDATCR }\end{array}$ \\
\hline$\beta_{4}$ & & $n=6$ & $\mathrm{n}=4$ & $\mathrm{n}=12$ \\
\hline \multirow[t]{2}{*}{$\gamma_{2}$} & 7750 & $\begin{array}{l}\text { MEANIDR } \\
\text { KLVEQLK } \\
\text { EDPLLTPVPASENPFR }\end{array}$ & $\begin{array}{l}\text { MEANIDR } \\
\text { KLVEQLK } \\
\text { EDPLLTPVPASENPFR }\end{array}$ & $\begin{array}{l}\text { AAADLMAYCEAHAK } \\
\text { KLVEQLK } \\
\text { EDPLLTPVPASENPFR }\end{array}$ \\
\hline & & $\mathrm{n}=6$ & $\mathrm{n}=6$ & $n=6$ \\
\hline$\gamma_{4}$ & & $\begin{array}{l}\text { EDPLIIPVPASENPFR } \\
\text {-MKEGMSNNSTTSISQAR }\end{array}$ & $\begin{array}{l}\text { EDPLIIPVPASENPFR } \\
\text {-MKEGMSNNSTTSISQAR }\end{array}$ & $\begin{array}{l}\text { EDPLIIPVPASENPFR } \\
\text {-MKEGMSNNSTTSISQAR } \\
\text { EGMSNNSTTSISQAR } \\
\text { VSQAAADLLAYCEAHVR }\end{array}$ \\
\hline$\gamma_{5}$ & & $\mathrm{n}=4$ & $n=4$ & $\mathbf{n}=\mathbf{5}$ \\
\hline \multirow[t]{2}{*}{$\gamma_{7}$} & 7379 & NDPLLVGVPASENPFK & NDPLLVGVPASENPFK & $\begin{array}{l}\text { NDPLLVGVPASENPFK } \\
\text { KLVEQLR }\end{array}$ \\
\hline & & $\mathbf{n}=\mathbf{2}$ & $\mathbf{n}=\mathbf{2}$ & $n=4$ \\
\hline \multirow[t]{2}{*}{$\gamma_{10}$} & 7105 & $\begin{array}{l}\text { LEAGVER } \\
\text { DALLVGVPAGSNPFR } \\
\text { DALLVGVPAGSNPFREPR }\end{array}$ & $\begin{array}{l}\text { LEAGVER } \\
\text { DALLVGVPAGSNPFR } \\
\text { DALLVGVPAGSNPFREPR }\end{array}$ & $\begin{array}{l}\text { VSQAAAELQQYCMQNACK } \\
\text { DALLVGVPAGSNPFR }\end{array}$ \\
\hline & & $n=6$ & $\mathrm{n}=4$ & $\mathbf{n}=\mathbf{3}$ \\
\hline
\end{tabular}




\begin{tabular}{|c|c|c|c|c|}
\hline Isoform & M.W. & $A_{1}: \alpha_{i 1}$ vs $S f 9 \beta \gamma$ & $A_{1}: a_{i 1}$ vs $A_{2 A}: a_{S}$ & $\begin{array}{l}A_{1}: a_{i 1} \text { vs Enriched } \\
\text { HEK-293 } \beta \gamma \text { Fraction } \\
\end{array}$ \\
\hline$\gamma_{11}$ & & $n=7$ & $\mathrm{n}=\mathbf{2}$ & $\mathrm{n}=1$ \\
\hline \multirow[t]{2}{*}{$\gamma_{12}$} & 7864 & $\begin{array}{l}\text { LEASIER } \\
\text { RTVQQLR } \\
\text { TASTNNIAQAR } \\
\text { ASADLMSYCEEHAR } \\
\text { SDPLLIGIPTSENPFK } \\
\text { SDPLLIGIPTSENPFKDK }\end{array}$ & $\begin{array}{l}\text { LEASIER } \\
\text { RTVQQLR } \\
\text { TASTNNIAQAR } \\
\text { ASADLMSYCEEHAR } \\
\text { SDPLLIGIPTSENPFK } \\
\text { SDPLLIGIPTSENPFKDK }\end{array}$ & $\begin{array}{l}\text { LEASIER } \\
\text { TASTNNIAQAR } \\
\text { ASADLMSYCEEHAR } \\
\text { SDPLLIGIPTSENPFK } \\
\text { SDPLLIGIPTSENPFKDK }\end{array}$ \\
\hline & & $\mathrm{n}=12$ & $\mathrm{n}=12$ & $\mathrm{n}=12$ \\
\hline
\end{tabular}




\section{Table 4}

Mean total percent of $\beta$ and $\gamma$ isoforms quantified in enriched HEK-293 fraction (A and B) and in $\beta \gamma$ dimers purified from $\mathrm{A}_{2 \mathrm{~A}}: a_{S}$ fusion protein $(C$ and $D)+/-$ SEM. Asterisks indicate significant differences in comparisons between levels of $\beta$ isoforms ( $A$ and $C$ ) and $\gamma$ isoforms (B and D) within a sample, ns $=$ not significant. Only one observed $\gamma_{11}$ peptide in one experiment (B) precluded statistical comparison with other $\gamma$ isoforms.

\begin{tabular}{|c|c|c|c|c|c|c|c|}
\hline & \multicolumn{7}{|c|}{ Enriched HEK-293 $\beta \gamma$ Fraction } \\
\hline $\mathbf{A}$ & $\%$ Total $\beta$ & $\beta_{1}$ & $\beta_{2}$ & $\beta_{4}$ & \multirow{4}{*}{\multicolumn{3}{|c|}{$\begin{array}{ll}* & p<0.05 \\
* \star & p<0.01 \\
* \star * & p<0.001\end{array}$}} \\
\hline$\beta_{1}$ & $66.1+1-2.7$ & & *** & $\star \star \star *$ & & & \\
\hline$\beta_{2}$ & $30.1+1-1.2$ & & & *** & & & \\
\hline$\beta_{4}$ & $3.7+/-0.2$ & & & & & & \\
\hline B & $\%$ Total $\gamma$ & $\gamma_{2}$ & $\gamma_{5}$ & $\gamma_{7}$ & $\gamma_{10}$ & $\gamma_{11}$ & $\gamma_{12}$ \\
\hline$\gamma_{2}$ & $11.2+/-1.6$ & & *** & ** & * & & ** \\
\hline$\gamma_{5}$ & $61.8+/-3.4$ & & & $* * *$ & $* * *$ & & *** \\
\hline$\gamma_{7}$ & $3.2+/-0.3$ & & & & * & & $* \star *$ \\
\hline$\gamma_{10}$ & $5.2+/-0.7$ & & & & & & 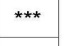 \\
\hline$\gamma_{11}$ & 0.08 & & & & & & $* * *$ \\
\hline$\gamma_{12}$ & $18.6+/-1.2$ & & & & & & \\
\hline & & rराm & ied $f$ & the & $A_{2 A}: \alpha_{S}$ & & \\
\hline & $\%$ Total $\beta$ & $\beta_{1}$ & $\beta_{2}$ & $\beta_{4}$ & & & \\
\hline$\beta_{1}$ & $65.0+1-3.0$ & & *** & $* * *$ & & $p<$ & 0.05 \\
\hline$\beta_{2}$ & $28.3+1-0.7$ & & & *** & & $p<$ & 0.01 \\
\hline$\beta_{4}$ & $6.8+/-0.6$ & & & & & *** $p<$ & 0.001 \\
\hline L & $\%$ Total $\gamma$ & $\gamma_{2}$ & $\gamma_{5}$ & $\gamma_{7}$ & $\gamma_{10}$ & $\gamma_{11}$ & $\gamma_{12}$ \\
\hline$\gamma_{2}$ & $6.7+/-0.2$ & & *** & *** & *** & *** & *** \\
\hline$\gamma_{5}$ & $75.0+/-2.9$ & & & $* * *$ & $* * *$ & $* * *$ & $* * *$ \\
\hline$\gamma_{7}$ & $2.1+/-0.4$ & & & & ns & * & $\star \star \star *$ \\
\hline$\gamma_{10}$ & $2.4+/-0.5$ & & & & & * & 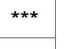 \\
\hline$\gamma_{11}$ & $0.05+/-0.03$ & & & & & & $* \star *$ \\
\hline$\gamma_{12}$ & $13.3+/-0.7$ & & & & & & \\
\hline
\end{tabular}

